\title{
Indicators of home-based hospitalization model and strategies for its implementation: a systematic review of reviews
}

Christiane Pereira Martins Casteli ${ }^{1,2}$, Gisèle Irène Claudine Mbemba', Serge Dumont ${ }^{3,4}$, Clémence Dallaire ${ }^{1,5}$, Lucille Juneau ${ }^{2,6}$, Elisabeth Martin ${ }^{1,4}$, Marie-Claude Laferrière ${ }^{7}$ and Marie-Pierre Gagnon ${ }^{1,5^{*}}$ (D)

\begin{abstract}
Background: Home-based hospitalization $(\mathrm{HBH})$ offers an alternative delivery model to hospital care. There has been a remarkable increase in pilot initiatives and deployment of this model to optimize services offered to a population with a variety of progressive and chronic diseases. Our objectives were to systematically summarize the indicators of HBH as well as the factors associated with the successful implementation and use of this model.

Methods: We used a two-stage process. First, five databases were consulted, with no date delimitation. We included systematic reviews of quantitative, qualitative, and mixed studies published in English, French, Spanish, or Portuguese. We followed guidance from PRISMA and the Cochrane Collaboration. Second, we used the Nursing Care Performance Framework to categorize the indicators, a comprehensive grid of barriers and facilitators to map the factors affecting $\mathrm{HBH}$ implementation, and a thematic synthesis of the qualitative and quantitative findings.

Results: Fifteen reviews were selected. We identified 26 indicators related to nursing care that are impacted by the use of $\mathrm{HBH}$ models and 13 factors related to their implementation. The most frequently documented indicators of $\mathrm{HBH}$ were cost of resources, problem and symptom management, comfort and quality of life, cognitive and psychosocial functional capacity, patient and caregiver satisfaction, hospital mortality, readmissions, and length of stay. Our review also highlighted new indicators, namely use of hospital beds, new emergency consultations, and use of healthcare services as indicators of resources of cost, and bowel complications, caregiver satisfaction, and survival time as indicators of change in the patient's condition. The main facilitators for $\mathrm{HBH}$ implementation were related to internal organizational factors (multidisciplinary collaboration and skill mix of professionals) whereas barriers were linked to the characteristics of the HBH, specifically eligibility criteria (complexity and social situation of the patient).

(Continued on next page)
\end{abstract}

\footnotetext{
* Correspondence: marie-pierre.gagnon@fsi.ulaval.ca

${ }^{1}$ Faculty of Nursing Sciences, Université Laval, Québec City, QC, Canada

${ }^{5}$ Research Center of the CHU de Québec-Université Laval, 1050 Avenue de la Médecine. Pavillon Ferdinand-Vandry, Québec City, QC G1VOA6, Canada

Full list of author information is available at the end of the article
} 
(Continued from previous page)

Conclusion: To the best of our knowledge, this is the first review that synthesizes both the types of indicators associated with $\mathrm{HBH}$ and the factors that influence its implementation. Considering both the processes and outcomes of $\mathrm{HBH}$ will help to identify strategies that could facilitate the implementation and evaluation of this innovative model of care delivery.

Systematic review registration: PROSPERO CRD42018103380

Keywords: Home-based hospitalization, Home hospital, Home care, Systematic review, Meta-analysis

\section{Background}

With the aging population and the growing prevalence of chronic diseases affecting all age groups, the integration of home care services is becoming a necessity for front line health service organizations around the world [1-3]. Since hospitalization is one of the key factors in the increasing cost associated with the use of health services related to chronic diseases, it is essential to implement effective and safe alternatives to conventional hospitalization [4].

All over the world, emergency room overflows reflect on suboptimal performance of the healthcare system as it is currently organized and delivered [5-7]. In addition, hospitalization in emergency departments entails significant risks for older adults, including iatrogenic complications, functional and cognitive decline, and loss of independence $[8,9]$.

Home-based hospitalization $(\mathrm{HBH})$ offers an alternative model of care delivery subject to the same obligations as hospitals $[10,11]$. The terminology regarding this service model is inconsistent in the literature as many studies use hospital-based home, hospital at home, hospital in the home, and home-hospitalization. In some cases, these terms are used but do not involve substitution for in-hospital care. The operational definition for $\mathrm{HBH}$ that we adopt in this paper is a service that provides in-home hospital care to patients with complex clinical conditions who would be hospitalized in conventional facilities due to an acute episode [12] and require $24 / 7$ monitoring and follow-up that is only available in the hospital [13]. The implementation of $\mathrm{HBH}$ would therefore optimize the use of resources by providing health services for specific groups who do not require conventional hospitalization.

In this regard, several countries, including the USA [14], Spain [15], Australia [16], Canada [17], and the UK [18], have implemented $\mathrm{HBH}$, following the example of France which was one of the first jurisdictions to implement it [19, 20]. The criteria for home admission are very heterogeneous, and the activity of $\mathrm{HBH}$ care varies greatly according to the main management methods: complex dressings, palliative care, and intensive nursing interventions [21].

A brief summary of Cochrane systematic reviews and meta-analyses comparing conventional hospitalization and $\mathrm{HBH}$ reveals that $\mathrm{HBH}$ would substantially optimize hospital bed [22] and would have a small advantage in readmissions $[12,20,23]$ and patient satisfaction [22, 24, 25]. However, there was no significant difference between the two modalities of care in terms of cost (reduced length of stay in hospital) or improved health outcomes, including reduced mortality [20, 22-24, 26].

The heterogeneity between systematic reviews reveals the varying degree of structuring of home care services with respect to the characteristics of the population and organization of services, the measures used, and the results reported [12, 27]. Thus, it becomes a challenge to find the most advantageous model. Despite the growing interest in $\mathrm{HBH}$ models, their implementation is still difficult for countries that do not have national and federal standards governing this practice [9, 13]. In general, arrangements for organizing $\mathrm{HBH}$ services, team composition, and organization of health professionals, as well as patient care and follow-up visits, are not well defined in the studies and precluding firm conclusions [12, 27, 28]. This limits the possibility to understand how organizational, clinical, economic, political, and social factors influence the implementation of this model of care.

The lack of knowledge about implementation factors compromises the identification of the expected effects in the delivery of $\mathrm{HBH}$ care and services. It also limits knowledge transfer about the organizational structure required to adopt this model of care between countries that have a comparable health system.

\section{Why do this systematic review of reviews?}

Several systematic reviews and meta-analyses have assessed a wide range of indicators related to $\mathrm{HBH}$, including the cost of providing hospital-based home care compared to conventional hospitalization. However, these indicators are not organized into a structured framework and their measurement vary between studies, which makes difficult providing clear evidence of the effects of $\mathrm{HBH}$ on important outcomes. Moreover, no previous reviews have systematically synthesized evidence on the factors associated with the implementation of $\mathrm{HBH}$ models. Indeed, the implementation of a new model of care is synonymous with major changes and transformations in the organization of services 
as well as at the clinical, economic, political, and social levels $[29,30]$.

This synthesis highlights the facilitating and limiting factors for $\mathrm{HBH}$ implementation together with its indicators, thus contributing to the knowledge base regarding this innovative model of care delivery for healthcare organizations.

\section{Objectives}

Systematically mapping the indicators of $\mathrm{HBH}$ as well as the factors associated with the success of the implementation and use of this model of care.

More specifically, this review covers the following questions: (1) What barriers and facilitating factors influenced the implementation of the $\mathrm{HBH}$ model? (2) What indicators (positive, negative, or neutral indicator) have been used to measure the HBH model?

\section{Methods}

\section{Study design}

As there are currently no guidance on reporting systematic reviews of reviews, we used the "Preferred Reporting Items for Systematic Review and Meta-Analysis" extension for network meta-analyses (PRISMA-NMA) guidelines [31] as a general framework to report this work. We also consulted methodological references on overviews of systematic reviews [32-34]. The PRISMA-NMA guidelines which contains 27 -item checklist and a fourphase flow diagram.

This review was structured according to the formulation of the PICOS research question (Population, Intervention, Comparison, Outcomes, Study Designs) [32] which forms the basis for establishing the components and eligibility criteria for studies (Table 1). Our PROSPERO protocol indicates the population of patients with chronic diseases, more specifically in palliative care because it was the target population of the larger project. However, we decided during the elaboration of the research strategy to expand the population including

Table 1 Definition of PICOS criteria for the eligibility of studies

Population Patients with chronic diseases, acute conditions, or in palliative care

Intervention Home-based hospitalization ( $\mathrm{HBH})$

Comparaison Conventional hospital care

Outcomes Primary: indicators of HBH use on access, continuity, quality, and safety of care, clinical practices, organization of health services, costs at the patient, family, health system, and society levels

Secondary: facilitating factors and barriers to the implementation of $\mathrm{HBH}$ at the environmental, organizational, staff, patient, and family levels. mixed-methods studies, with or without meta-analysis also patients in acute conditions in order to favor the inclusion of different models of $\mathrm{HBH}$.

The methodological quality assessment grid for systematic reviews (AMSTAR 2) was used for assessing the quality of systematic reviews and meta-analyses included [35].

The nursing care performance framework (NCPF), developed by Dubois [36] (Appendix 1), has been adapted to map the indicators of $\mathrm{HBH}$ identified from systematic reviews. This model allows the systematic evaluation of the healthcare system in general, including nursing care, and its three subsystems (acquiring, maintaining, and deploying resources; transforming resources into services; producing changes in patient conditions). It proposes 14 dimensions and 51 indicators that allow performance evaluation of the whole nursing system using a multidimensional perspective that includes structure, process, and results and takes into account the influence of external factors.

The NCPF was chosen because in the HBH model, the coordination of care is centered on nursing practice [11, 37-39]. This model provides a group of indicators to evaluate nursing performance in the organizational model of $\mathrm{HBH}$ that could serve as a basis to orient evaluation of this model of care.

Regarding the factors that influenced the implementation of the HBH model, we adapted the concepts developed through research related to the classification of barriers and facilitators to implementing innovative technologies in healthcare [40-43]. This conceptual approach allows an explanation of the factors affecting the implementation and use of the $\mathrm{HBH}$ model in a complex and dynamic environment inherent to the healthcare system and defines the determinants of the adoption and diffusion of this innovation.

\section{Protocol}

The protocol for this review is registered in the international prospective register of systematic reviews (PROSPERO) under number CRD42018103380. We brought some changes to the protocol as we did not limit the population to $\mathrm{HBH}$ for palliative care, but rather included all populations that could benefit from $\mathrm{HBH}$, since the included systematic reviews often considered several population groups or diseases. We also considered all relevant outcomes reported in the included systematic reviews.

\section{Inclusion and exclusion criteria}

Included publications were quantitative systematic reviews (including meta-analysis), qualitative reviews, and mixed studies reviews focusing on the factors associated with the implementation of $\mathrm{HBH}$ and its indicators of use, and published in English, French, Spanish, and Portuguese (languages spoken by the authors). As the 
first systematic review on $\mathrm{HBH}$ was published in 1998 [44], we did not delineate date limit for the search.

\section{Search strategy}

Five electronic databases (Medline (OVID), Embase, Cochrane Database of Systematic Reviews (CDSR), Database of Abstracts of Reviews of Effects (DARE), and CINAHL Plus with Full Text bibliographic databases using controlled and free terms) were searched between April and May 2018 and October 2019 (Appendix 2). The development of the search strategy in all selected bibliographic databases was carried out by two team members (CPMC, MCL) as the latter is a health librarian. The SIGN [SIGN] search filter was used by the specialist (MCL) to specify the research process with a predefined set of keywords to identify systematic reviews and meta-analyses. The results of each search were recorded in a bibliographic reference management software (EndNote). Duplicate references were eliminated.

\section{Selection of studies}

The selection was made independently by two team members (CPMC, GICM). First, the titles and summaries of the systematic reviews were reviewed and selected according to the inclusion criteria. Then, the complete texts were evaluated. Publications that did not meet the inclusion criteria were excluded by documenting the reasons for exclusion. Any disagreement concerning study eligibility was resolved through discussion and consensus involving both examiners or involved a third author, if necessary. A flowchart was used to show the overall process of selecting studies [45].

\section{Extraction of data}

Data from the included reviews were extracted independently by two team members (CPMC, GICM), as recommended by the Cochrane Handbook [32], using a form based on the components of the PICOS question and primary and secondary outcome indicators. The following data were extracted: characteristics of the review (authors, year of publication, language, type of review, rationale, objectives), characteristics of the population (patient profile, health status, and care environment), characteristics of the intervention (type of service provided, context of care, duration of the $\mathrm{HBH}$, intervention components, team composition, technologies used), comparisons between home and conventional hospitalization, primary and secondary outcomes (positive, negative, or neutral indicators of $\mathrm{HBH}$ and implementation determinants). For summarizing our qualitative findings, two team members (CPMC, GICM) adapted the grid with concepts developed through research related to the classification of barriers and facilitators to implementing innovative technologies in healthcare [40-43] as the analytical framework. CPMC and GICM independently performed data extraction and transposed extracted data into this framework using thematic analysis. We populated the data extraction grid in the Microsoft Excel software 2016. The quality of included reviews was independently assessed by the same two authors according to the AMSTAR 2 evaluation grid [35]. The strength of the evidence was assessed according to the GRADE approach [46].

\section{Data synthesis}

A narrative summary of the results of the included reviews was developed to describe the main indicators of $\mathrm{HBH}$ using the framework of Dubois [36]. Implementation factors were also synthesized narratively using the categories proposed by McGinn et al. [40] and Gagnon et al. [43]. The narrative approach is recommended to summarize and explain the results of systematic quantitative, qualitative, and mixed studies, especially the indicators of interventions and the implementation of interventions that have been shown to be effective $[47,48]$.

Specifically on implementation factors, the reviewers identified sections of the publications that presented a relevant barrier or facilitator to implementation and use of $\mathrm{HBH}$ model and coded them according to the categories proposed in the grid. Then, we grouped the extracted data into four main categories of adoption factors, and each category was decomposed into specific factors.

To achieve this, quantitative data were categorized according to the frequency of each factor and its influence (facilitator or barriers as well as the frequency of each indicator (positive, negative, or neutral indicators) of using $\mathrm{HBH}$ at the level of patient, family, healthcare system, and society. Qualitative data were integrated into a thematic synthesis.

\section{Results \\ Search results}

A total of 1069 records were identified from the search strategy. After removing duplicates and screening titles and abstracts, we examined 40 full texts, of which 15 reviews [12, 20, 22-26, 44, 49-55] were eligible for inclusion. All reviews showed indicators of $\mathrm{HBH}$ as well as the factors associated with the implementation and use of this model of care (by primary and secondary outcomes). However, the structure of included reviews did not allow us to present the outcomes by population groups. Appendixes 3 and 4 present the PRISMA extension checklist and the list of selected reviews with the frequency of primary studies, respectively. The overall process of review selection was summarized according to the PRISMA study flow diagram (Fig. 1), and details are provided regarding the primary reasons for exclusion and the full references of excluded publications (Appendix 5). 


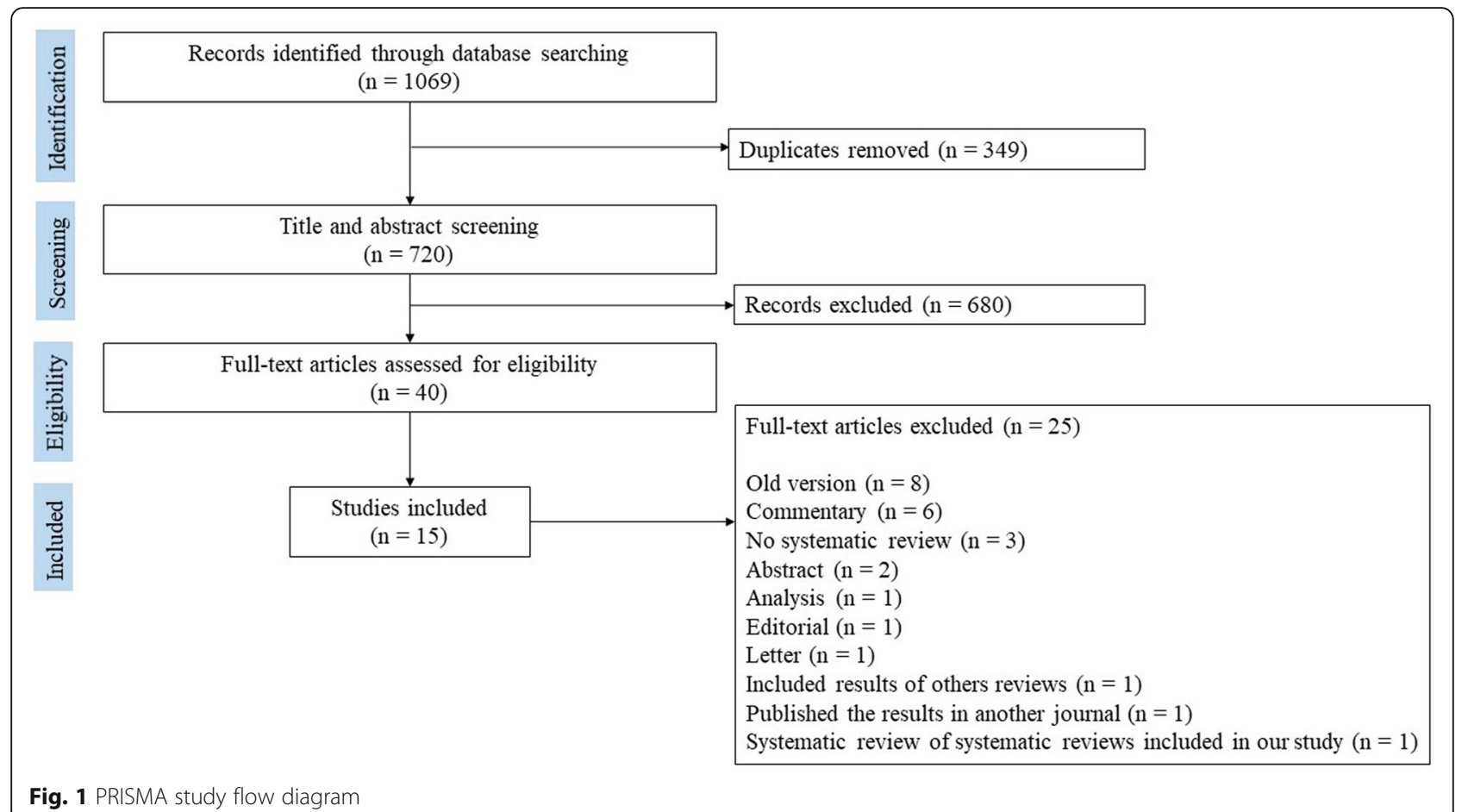

Fig. 1 PRISMA study flow diagram

\section{Characteristics of the reviews}

The general characteristics of the included reviews, namely type of review, population, intervention, outcomes, and quality, are summarized in Table 2 and detailed in Appendix 6.

All reviews were published in English, except one that was published in Spanish, between 1998 and 2018, and more than half were published since 2012 . The majority of reviews were from the UK $(n=9,60 \%)$. The other six reviews were from Canada $(n=1)$, Australia $(n=1)$, Norway $(n=1)$, Spain $(n=1)$, Belgium $(n=1)$, and Denmark $(n=1)$.

The majority of reviews included only quantitative studies $(n=12,80 \%)$ [12, 20, 22-26, 44, 49-52]. Three reviews (20\%) also included qualitative studies [53-55].

The most common population included in $\mathrm{HBH}$ programs were adult patients [12, 20, 22-26, 44, 49, 51, 52]. Only one review assessed the impact of hospital-based home care (HBHC) on children with cancer [50].

According to the AMSTAR 2, five of the reviews were of high quality $[3,22,24,25,49]$, eight reviews were of moderate quality $[20,23,26,51,52,55]$, and two reviews had a low quality score $[44,50]$.

\section{Profile of admitted patients in $\mathrm{HBH}$}

Fourteen reviews included patient populations aged 18 years and older needing treatment during an acute episode of care, who would otherwise require hospitalization [12, $20,22-26,44,49-55]$. The other review focused on children and adolescents aged $0-18$ years old [50].
Most reviews considered the provision of $\mathrm{HBH}$ to patients with a mix of medical conditions $(n=12 ; 80 \%)$, including chronic obstructive pulmonary disease (COPD), stroke, heart failure, elective surgery, pneumonia, psychiatric disease, pulmonary embolism, complicated diverticulitis, and cellulitis $[12,20,22,23,25,26,44,49,51$, $52,54,55]$. Two reviews included exclusively patients with cancer under chemotherapeutic treatment $[50,53]$, and one review focused on end-of-life patients [24].

\section{Overview of the indicators of $\mathrm{HBH}$}

The results (see Fig. 2) are presented in association with the NCPF [36]: the function, the dimension, and the indicators, according to the frequency of data extracted from each systematic review (Table 3) and with the strength of evidence of according to the GRADE [46] approach identified in the systematic reviews that used it (Appendix 7).

\section{Function 1: acquiring, deploying, and maintaining resources \\ Economic sustainability}

Almost all reviews (14/15) outlined positive indicators related to cost effectiveness of resources [12, 20, 23-26, $49,52-55]$, including the three new indicators identified in the $\mathrm{HBH}$ economic sustainability dimension of the NCPF, namely use of hospital beds [24], new emergency consultations [49, 54], and use of healthcare services [24]. Only one review did not evaluate the cost [54]. The cost per episode of healthcare or per day basis associated 
Table 2 Summary of characteristics of included studies

\begin{tabular}{|c|c|c|c|c|c|}
\hline Author, year, country & $\begin{array}{l}\text { Type of reviews or } \\
\text { designs }\end{array}$ & Population & Intervention & Outcomes & AMSTAR \\
\hline $\begin{array}{l}\text { Cool et al. , } 2018 \text { [53], } \\
\text { Belgium }\end{array}$ & $\begin{array}{l}\text { Systematic review } \\
\text { Mixed }\end{array}$ & Adult patients & $\begin{array}{l}\text { Parenteral cancer drug } \\
\text { administration }\end{array}$ & $\begin{array}{l}\text { Quality of life, patient's satisfaction, } \\
\text { safety, and costs }\end{array}$ & $\overline{\text { Moderate }}$ \\
\hline $\begin{array}{l}\text { Corral Gudino et al. , } \\
2017 \text { [54], Spain }\end{array}$ & $\begin{array}{l}\text { Systematic review } \\
\text { Qualitative }\end{array}$ & Not specified & $\begin{array}{l}\text { Interventions supporting } \\
\text { continuity of care, } \\
\text { including } \mathrm{HBH}\end{array}$ & $\begin{array}{l}\text { Number of readmissions, mortality, } \\
\text { or improvement in functional } \\
\text { capacity }\end{array}$ & Moderate \\
\hline $\begin{array}{l}\text { Goncalves-Bradley } \\
\text { et al. , } 2017 \text { [22], UK }\end{array}$ & $\begin{array}{l}\text { Systematic review } \\
\text { and meta-analysis } \\
\text { Quantitative }\end{array}$ & $\begin{array}{l}\text { Patients aged } \\
18 \text { years and } \\
\text { over }\end{array}$ & $\begin{array}{l}\text { Early discharge hospital } \\
\text { at home }\end{array}$ & $\begin{array}{l}\text { Effectiveness and cost of the } \\
\text { intervention }\end{array}$ & High \\
\hline $\begin{array}{l}\text { Huntley et al. [55], } \\
\text { 2017, UK }\end{array}$ & $\begin{array}{l}\text { Systematic review } \\
\text { Qualitative }\end{array}$ & $\begin{array}{l}\text { Patients aged } \\
\text { over } 65 \text { years }\end{array}$ & $\begin{array}{l}\text { Any community-based } \\
\text { intervention offered as } \\
\text { an alternative to } \\
\text { admission to an acute } \\
\text { hospital }\end{array}$ & $\begin{array}{l}\text { Reduction in secondary care use, } \\
\text { patient-related outcomes, safety, } \\
\text { and costs }\end{array}$ & Moderate \\
\hline $\begin{array}{l}\text { Shepperd et al. , } \\
\text { 2016a [24], UK }\end{array}$ & $\begin{array}{l}\text { Systematic review } \\
\text { and meta-analysis } \\
\text { Quantitative }\end{array}$ & $\begin{array}{l}\text { People aged } \\
18 \text { years and } \\
\text { older }\end{array}$ & $\begin{array}{l}\text { Home-based end-of-life } \\
\text { care }\end{array}$ & $\begin{array}{l}\text { Place of death, admission to } \\
\text { hospital, patient satisfaction, } \\
\text { caregiver burden, health service } \\
\text { costs. }\end{array}$ & High \\
\hline $\begin{array}{l}\text { Shepperd et al. , } \\
\text { 2016b [25], UK }\end{array}$ & $\begin{array}{l}\text { Systematic review } \\
\text { and meta-analysis } \\
\text { Quantitative }\end{array}$ & $\begin{array}{l}\text { Patients aged } \\
18 \text { years and } \\
\text { over. }\end{array}$ & Hospital at home & $\begin{array}{l}\text { Mortality, transfer to hospital, place } \\
\text { of residence, length of stay, patient } \\
\text { satisfaction, cost }\end{array}$ & High \\
\hline $\begin{array}{l}\text { Echevarria et al. , } \\
2016 \text { [23], UK }\end{array}$ & $\begin{array}{l}\text { Systematic review } \\
\text { and meta-analysis } \\
\text { Quantitative }\end{array}$ & $\begin{array}{l}\text { Patients with } \\
\text { acute } \\
\text { exacerbation } \\
\text { of chronic } \\
\text { obstructive } \\
\text { pulmonary } \\
\text { disease }\end{array}$ & $\begin{array}{l}\text { Early supported discharge } \\
\text { (ESD) and hospital at } \\
\text { home (HAH) }\end{array}$ & Readmissions, mortality, and cost. & Moderate \\
\hline $\begin{array}{l}\text { Qaddoura et al. , } \\
2015 \text { [49], Canada }\end{array}$ & $\begin{array}{l}\text { Systematic review } \\
\text { and meta-analysis } \\
\text { Quantitative }\end{array}$ & $\begin{array}{l}\text { Patients who } \\
\text { required } \\
\text { hospitalization } \\
\text { for } \\
\text { decompensated } \\
\text { heart failure }\end{array}$ & Substitutive care models & $\begin{array}{l}\text { Mortality, hospital readmissions, } \\
\text { other clinical, patient-centered, and } \\
\text { cost outcomes }\end{array}$ & High \\
\hline $\begin{array}{l}\text { Caplan et al. , } \\
2012 \text { [20], Australia }\end{array}$ & $\begin{array}{l}\text { Systematic review } \\
\text { and meta-analysis } \\
\text { Quantitative }\end{array}$ & $\begin{array}{l}\text { Patients aged } \\
>16 \text { years }\end{array}$ & $\begin{array}{l}\text { Hospital at home care } \\
\text { models }\end{array}$ & $\begin{array}{l}\text { Mortality, readmission rates, patient } \\
\text { and carer satisfaction, and costs }\end{array}$ & Moderate \\
\hline $\begin{array}{l}\text { Jeppesen et al. , } \\
2012 \text { [12], Norway }\end{array}$ & $\begin{array}{l}\text { Systematic review } \\
\text { and meta-analysis } \\
\text { Quantitative }\end{array}$ & $\begin{array}{l}\text { Patients with a } \\
\text { diagnosis of } \\
\text { COPD with an } \\
\text { acute } \\
\text { exacerbation }\end{array}$ & Hospital at home care & $\begin{array}{l}\text { Readmission rate, mortality, costs, } \\
\text { and days of care provision }\end{array}$ & High \\
\hline $\begin{array}{l}\text { Hansson et al. , } \\
2011 \text { [50], Denmark }\end{array}$ & $\begin{array}{l}\text { Systematic review } \\
\text { Quantitative }\end{array}$ & $\begin{array}{l}\text { Children and } \\
\text { adolescents } \\
\text { aged } 0-18 \text { years } \\
\text { with a cancer } \\
\text { diagnosis }\end{array}$ & $\begin{array}{l}\text { Care in the patient's own } \\
\text { home as an alternative } \\
\text { to a hospital admission }\end{array}$ & $\begin{array}{l}\text { Children's physical health and } \\
\text { adverse events, satisfaction and } \\
\text { quality of life of children and their } \\
\text { parents, and costs }\end{array}$ & Low \\
\hline $\begin{array}{l}\text { Shepperd et al. , } \\
2009[51], \text { UK }\end{array}$ & $\begin{array}{l}\text { Systematic review } \\
\text { and meta-analysis } \\
\text { Quantitative }\end{array}$ & $\begin{array}{l}\text { Patients aged } \\
18 \text { years and } \\
\text { over }\end{array}$ & $\begin{array}{l}\text { Early discharge hospital } \\
\text { at home }\end{array}$ & $\begin{array}{l}\text { Mortality, readmissions, patient } \\
\text { satisfaction, length of stay in } \\
\text { hospital and hospital at home, cost }\end{array}$ & Moderate \\
\hline $\begin{array}{l}\text { Shepperd et al , } \\
2008[52] \text {, UK }\end{array}$ & $\begin{array}{l}\text { Systematic review } \\
\text { and meta-analysis } \\
\text { Quantitative }\end{array}$ & $\begin{array}{l}\text { Patients aged } \\
18 \text { years and } \\
\text { older }\end{array}$ & Hospital care at home & $\begin{array}{l}\text { Mortality, readmissions or transfers } \\
\text { to hospital, patient and caregiver } \\
\text { satisfaction, place of residence at } \\
\text { follow-up, length of stay, and cost }\end{array}$ & Moderate \\
\hline $\begin{array}{l}\text { Felix et al. , } \\
2004 \text { [26], UKK }\end{array}$ & $\begin{array}{l}\text { Systematic review } \\
\text { and meta-analysis } \\
\text { Quantitative }\end{array}$ & Adult patients & $\begin{array}{l}\text { Hospital at home } \\
\text { schemes }\end{array}$ & Mortality and readmission & Moderate \\
\hline $\begin{array}{l}\text { Shepperd et al. , } \\
1998 \text { [44], UK }\end{array}$ & $\begin{array}{l}\text { Systematic review } \\
\text { Quantitative }\end{array}$ & $\begin{array}{l}\text { Patients aged } 18 \\
\text { years and over }\end{array}$ & Hospital at home care & $\begin{array}{l}\text { Mortality, re-admissions, costs, patient } \\
\text { satisfaction, and carer satisfaction }\end{array}$ & Low \\
\hline
\end{tabular}




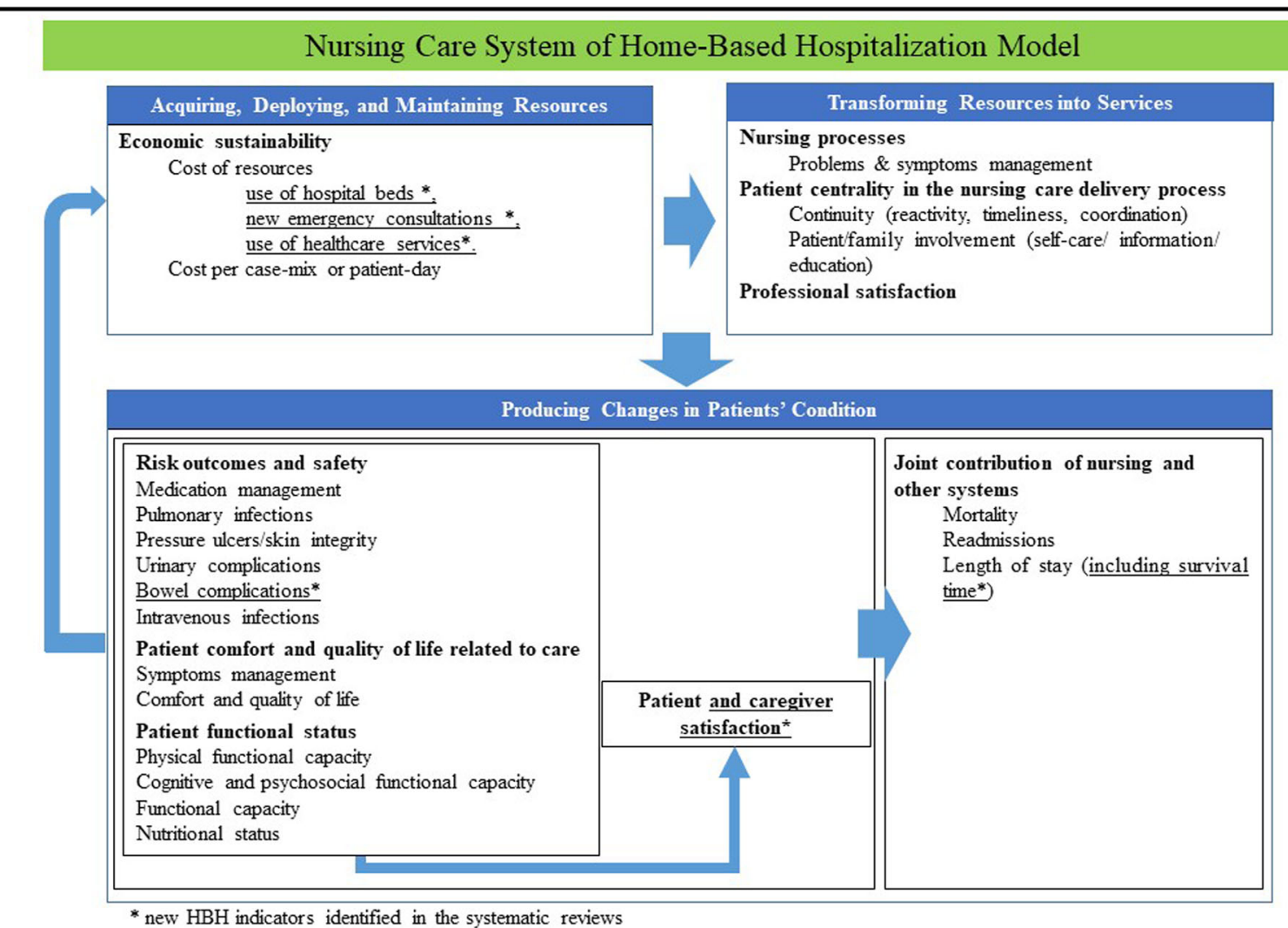

Fig. 2 Presentation of results about indicators of $\mathrm{HBH}$ model

with $\mathrm{HBH}$ was consistently lower than usual care [12, $20,23,24,52,53,55]$, and there could also be a saving of bed days a year, according to one review [26].

However, this benefit is offset when costs from a societal perspective were also considered, including formal and informal carer costs and production losses for the patient, over the acute and follow-up periods combined $[20,23,24,52]$. Some evidence indicates the possibility of substantial variation in the actual effect size [12, 22, $44,49-51]$ by patient eligibility criteria [20,52], different countries, and various conditions [12].

Due to different methods to calculate costs and heterogeneity due to different currencies and different cost structures, identifying the cost-effectiveness of $\mathrm{HBH}$ model was not possible in some reviews [22, 44, 49-51].

\section{Function 2: transforming resources into services Nursing processes}

Three reviews found a positive indicator of $\mathrm{HBH}$ on problem and symptom management $[22,49,55]$ whereas one review found neutral indicator [12]. Among the documented outcomes, HBH reduced delirium [22] and provided improvements for depression [49, 55] and nutritional status at 6 months follow-up [49].

\section{Patient centrality in the nursing care delivery process}

One review that documented continuity (reactivity) for patients and patient/family involvement (self-care/information/education) showed a positive indicator of $\mathrm{HBH}$ [23]. This review found that patient and carer education for recognition and management of acute exacerbation was associated with a lower rate of all-cause readmission.

In relation to informal caregivers, also considered users of this model of care, a review does not report any indicator of the $\mathrm{HBH}$ model on them, justifying the lack of data on the impact of home hospitalization on the family or informal caregivers [22]. This review indicates that the caregiver's willingness to take on the responsibilities associated with $\mathrm{HBH}$ is a determining factor that may restrict the degree to which $\mathrm{HBH}$ model can be implemented, and this may in turn impact on how these services reduce costs and reliance on secondary care in general [22].

\section{Professional satisfaction}

Professional satisfaction was reported in three reviews $[22,25,51]$. Indicators of professional satisfaction were mixed within and across the reviews: two reviews demonstrated positive indicators $[22,51]$, and one demonstrated negative indicator [25]. 
Table 3 Frequency and direction of reported indicators of $\mathrm{HBH}$ according to the NCPF

\begin{tabular}{|c|c|c|c|}
\hline \multirow[t]{2}{*}{ Subsystems, dimensions, and indicators from the NCPF } & \multicolumn{3}{|c|}{ No. of systematic reviews and meta-analyses } \\
\hline & $\begin{array}{l}\text { Positive indicators } \\
\text { of } \mathrm{HBH}\end{array}$ & $\begin{array}{l}\text { Negative indicators } \\
\text { of } \mathrm{HBH}\end{array}$ & $\begin{array}{l}\text { Neutral indicators } \\
\text { of } \mathrm{HBH}\end{array}$ \\
\hline \multicolumn{4}{|l|}{ 1. Acquiring, deploying and maintaining nursing resources } \\
\hline \multicolumn{4}{|l|}{ Economic sustainability } \\
\hline Cost of resources & 9 & - & 5 \\
\hline Use of hospital beds* & 1 & - & - \\
\hline New emergency consultations* & 2 & - & - \\
\hline Use of healthcare services* & 1 & - & - \\
\hline Cost per case-mix or patient-day & 1 & - & - \\
\hline \multicolumn{4}{|l|}{ 2. Transforming nursing resources into relevant nursing services } \\
\hline \multicolumn{4}{|l|}{ Nursing processes } \\
\hline Problem and symptom management & 3 & - & 1 \\
\hline \multicolumn{4}{|l|}{ Patient centrality in the nursing care delivery process } \\
\hline Continuity (reactivity, timeliness, coordination) & 1 & - & - \\
\hline Patient/family involvement (self-care/information/education) & 1 & - & 1 \\
\hline Professional satisfaction & 2 & 1 & - \\
\hline \multicolumn{4}{|l|}{ 3. Producing changes in patients' conditions } \\
\hline \multicolumn{4}{|l|}{ Risk outcomes and safety } \\
\hline Medication management: errors and complications & - & 1 & 2 \\
\hline Pulmonary infections & - & 1 & - \\
\hline Pressure ulcers/skin integrity & - & 1 & - \\
\hline Urinary complications & 1 & - & - \\
\hline Bowel complications* & 1 & - & - \\
\hline Intravenous infections & - & 2 & - \\
\hline \multicolumn{4}{|l|}{ Patient comfort and quality of life related to care } \\
\hline Symptom management (e.g., pain, nausea, dyspnea, fever) & 3 & - & - \\
\hline Comfort and quality of life (taken broadly) & 5 & - & 3 \\
\hline \multicolumn{4}{|l|}{ Patient functional status } \\
\hline Physical functional capacity & - & 1 & - \\
\hline Cognitive and psychosocial functional capacity & 5 & - & 1 \\
\hline Functional capacity & 1 & - & 4 \\
\hline Nutritional status & 2 & - & - \\
\hline \multicolumn{4}{|l|}{ Patient and caregivers satisfaction } \\
\hline Patient satisfaction/complaints & 11 & 1 & 2 \\
\hline Satisfaction of caregivers and complaints* & 4 & 2 & 3 \\
\hline \multicolumn{4}{|l|}{ Joint contribution of nursing with other care } \\
\hline Hospital mortality & 5 & - & 7 \\
\hline Readmissions & 4 & - & 7 \\
\hline Length of stay & 6 & 1 & 2 \\
\hline Survival time* & - & - & 1 \\
\hline
\end{tabular}

*New HBH indicator identified in the systematic reviews and meta-analyses and integrated to the NCPF

Two reviews showed that the HBH staff perceived that providing care in the patient home facilitated participation in rehabilitation, that the service was better staffed than the usual discharge services provided, although the workload was similar to conventional hospitalization [22, 51]. However, the evaluation of health professionals' perceptions about $\mathrm{HBH}$, specifically that of general practitioners, presented limitations due to low response rate [25], although it 
was higher when compared to the response rate of conventional hospital staff [25].

\section{Function 3: producing changes in patients' condition Risk outcomes and safety}

Three reviews found negative indicators $[25,50,53]$, two reviews found neutral indicators $[53,55]$, and one found positive indicators [25] on risk outcomes and safety.

The negative indicators included intravenous infections due to perfusion difficulties for which hospitalization was needed, device-related infection [53], and episodes of subcutaneous inflammation along intravenous lines [50]. Pressure ulcers/skin integrity was mentioned in the risk of advancing cellulitis in participants with cellulitis, and pulmonary infections were related to the increased antibiotic therapy for participants with COPD allocated to $\mathrm{HBH}$ [25]. Also, the need for management of drug administration was cited before the occurrence of occlusion of central venous catheters [50]. Nonetheless, two reviews mentioned that they found neutral indicators on medication management and that the adverse events described (number of reported toxicities, perfusion difficulties, missed doses, and adverse drug reactions) were comparable between $\mathrm{HBH}$ and usual care $[53,55]$.

The only review that found positive indicators cited the reduction in the number of urinary and bowel complications in patients allocated to $\mathrm{HBH}$ [25], the latter being a new indicator identified in the risk outcomes and safety dimension of the NCPF.

\section{Patient comfort and quality of life related to care}

Positive indicators on symptom management were reported in three reviews $[25,49,50]$. The control of symptoms in adult patients (pain, nausea/vomiting, constipation, diarrhea, breathlessness, anxiety, and depression) improved, but assessments varied by assessor [25]. Fewer patients with stroke allocated to $\mathrm{HBH}$ reported anxiety [49]. The successful control of nausea and vomiting in children was also highlighted [50].

Positive indicators on the quality of life $(\mathrm{QoL})$ of patients in $\mathrm{HBH}$ were reported in five reviews $[25,49-51,55]$, and other three reviews found no association between $\mathrm{HBH}$ and health-related quality of life indicators [12, 23, 53]. The improvement in QoL among HBH patients may be facilitated by treatment in a familiar environment, with greater independence and less technically oriented care [49]. Furthermore, HBH presented a significantly reduced risk to patients for being in residential care at follow-up [51]. An improvement was reported in QoL at both 6 months [25, 55] and 12 months, for patients with heart failure [55]. QoL in children and parents was overall improved when the child received intravenous chemotherapy at home with $\mathrm{HBH}[50]$.

\section{Patient functional status}

Five reviews found positive indicators in view of patient functional status $[25,49,51,52,55]$, five found neutral indicator $[22,24,25,51,52]$, and one found a negative indicator [55].

$\mathrm{HBH}$ patients experienced improvements in cognitive and psychosocial functional capacity with regard to depression $[49,52,55]$, especially in patients with stroke or acute chronic heart failure [25], and better psychological well-being for patient with stroke [51]. Fewer participants with a mix of conditions receiving $\mathrm{HBH}$ care experienced short-term confusion during an episode of care, and fewer participants with dementia were prescribed antipsychotic drugs [25] or had problems with sleep, agitation, aggression, and feeding [52].

Improvements in activities of daily living were also reported for patients with stroke, COPD, or heart failure at 6-month follow-up [25]. Nutritional status improved for adult patients with acute decompensation of chronic heart failure [49], and fewer patients with dementia assigned to $\mathrm{HBH}$ had problems with feeding [52].

The assessment of physical functional capacity for depression and anxiety did not differ between $\mathrm{HBH}$ and usual care due to insufficient evidence between groups for most measures $[25,51,52]$. The lack of indicator on functional capacity was also reported in two other reviews [22, 24]. The most recent review emphasized that $\mathrm{HBH}$ for end-oflife care may make little difference in functional status, psychological well-being, or cognitive status [24].

A negative indicator on physical functional capacity was reported in patients with stroke mentioning that these patients worsened with $\mathrm{HBH}$ intervention compared with treatment in a stroke unit [55].

\section{Patient and caregiver satisfaction}

In 11 reviews, patient satisfaction was higher with $\mathrm{HBH}$ [20, 22, 24, 25, 44, 49-53, 55], two reviews found neutral indicator, citing that patient satisfaction appears to be similar although further robust trials are required [12, 23], and one review found a negative indicator [51].

A considerable proportion of cancer patients, including children and their parents, preferred $\mathrm{HBH}[50,53]$. Most-valued aspects of $\mathrm{HBH}$ are the quality of communication, personal care received [25], frequent and timely visits, and close attention to details [51].

The negative indicator reported concerned women recovering from a hysterectomy and allocated to $\mathrm{HBH}$ who had to resume parental responsibilities before being well enough [51].

The satisfaction of informal caregivers was a new indicator documented in the dimension patient and caregiver satisfaction of the NCPF. Four reviews demonstrated positive indicators $[20,25,50,52]$, three showed 
neutral indicators [22, 25, 51], and two showed negative indicators $[25,44]$.

$\mathrm{HBH}$ increased caregiver satisfaction compared to conventional hospital care [20, 25, 44, 50, 52], notably by lowering relatives' stress [25], but did not affect carer burden [20] and anxiety of parents of children in $\mathrm{HBH}$ [50]. The caregivers reported that although hospital would potentially relieve them from caring, the upheaval of visiting hospital and the accompanying anxiety was a less satisfactory option [25].

However, the results on satisfaction are still uncertain, according to the weak evidence found in three reviews $[22,25,51]$, especially for caregivers of patients in endof-life care. Caregivers expressed lower levels of satisfaction with $\mathrm{HBH}$, compared with hospital care, and experienced lower morale if the participant survived more than 30 days. There was also little or no difference for caregiver bereavement response 6 months following patient's death $[25,44]$.

\section{Joint contribution of nursing with other care}

Seven reviews reported neutral indicators of $\mathrm{HBH}$ on mortality at 3- to 6-month follow-up [22, 24-26, 49, 51, 55]. However, positive indicators were described in five reviews that found a tendency to decrease mortality within 2 to 6 months favoring $\mathrm{HBH}$ in the middle age group [12, 20, 23, 52], and a reduction in mortality for patients with heart failure compared to conventional hospitalization [54].

$\mathrm{HBH}$ indicators on hospital readmission were neutral in seven reviews, as no strong evidence was found on the rate of readmission [22, 25, 26, 49, 51, 52, 55]. However, four reviews mentioned positive indicators with evidence of moderate quality related to the reduction of readmission for $\mathrm{HBH}$ patients compared to conventional hospitalization $[12,20,23,54]$, notably in patients with heart failure and COPD [54].

The difference in length of hospital stay varied among reviews, showing a reduction between 4 to 14 days [20, $24,55]$. The positive indicators of $\mathrm{HBH}$ on length of stay were documented in six reviews [22-24, 51, 52, 54], two reviews found neutral indicators due to the heterogeneity of the data $[25,55]$, and a negative indicator was reported in one review [49].

$\mathrm{HBH}$ reduced the length of stay for patients with a mix of conditions [22-24, 51, 52, 54]: COPD [54], stroke [22-24, 52], early discharge of patients following elective surgery [51]. However, the total period of care tends to be longer according to one review [23]. Another review showed a significantly longer length of stay in the $\mathrm{HBH}$ intervention, but this indicator might be due to the heterogeneity of the data [49].

With respect to survival, a new indicator identified in the dimension joint contribution of nursing with other care, one review found neutral indicator on survival time for $\mathrm{HBH}$ end-of-life care [25].

\section{Overview of the facilitators and barriers to the implementation of $\mathrm{HBH}$ model}

In total, 41 distinct facilitators and barriers to implementing $\mathrm{HBH}$ model were identified and classified in the different categories of factors from the extraction grid. Among these elements, 35 (85\%) were classified as facilitators for implementation of $\mathrm{HBH}$ and six (15\%) as barriers. The complete list of factors can be found in Table 4 .

\section{Factors related to $\mathrm{HBH}$ characteristics}

The included reviews were conducted in different countries with different healthcare systems. Nonetheless, there were some important common features about definition of $\mathrm{HBH}$, which included replacement of both acute and subacute hospitalization $[20,22]$ in complex patients with a high degree of comorbidity $[53,54]$ and different intensities of home-based care [20, 49]; care being coordinated in each of the schemes by a multidisciplinary team, home visits, provision of 24-h cover if required, with access to a doctor [12, 20, 23-25, 49, 52, 53] and monitoring, diagnostic testing, home nursing care for the administration of IV medications [49, 53], and a safe home environment [12, 20, 23, 25, 49, 52].

Regarding the factors related to the characteristics of $\mathrm{HBH}$, a total of eight elements pertain to this category, with two of them identified as barriers and six as facilitators. The most recurrent adoption factor was HBH characteristics, with five extracted elements. It was seen as a facilitator in three reviews $[20,23,55]$ and as a barrier in two reviews [23, 25]. The configuration of this innovation was characterized mainly by the condition of the individual's home and the social support networks existing in the $\mathrm{HBH}$ model [55] during the day and night [23]. Length of $\mathrm{HBH}$ stay was also considered a barrier in $\mathrm{HBH}$ model with limited duration [20]. In this context, nursing care available only in the last 2 weeks of life [25] and the heterogeneity of the level of clinical and social support provided in $\mathrm{HBH}$ [23] were two shortcomings in the HBH models.

Patient empowerment was mentioned as a facilitator in three reviews $[23,25,49]$. The educational component on self-management provided at home instrumented participants and their families to identify care goals and expected course of disease and outcomes, as well as the probability of success of various treatments $[23,25,49]$.

\section{Individual factors: knowledge, attitude, and socio- demographic characteristics}

Individual factors represented three of the elements identified in the review, two as facilitators and one as a 
Table 4 Frequency of factors identified as facilitators or barriers to the implementation of the $\mathrm{HBH}$ model

\begin{tabular}{ll}
\hline Factor & $\begin{array}{l}\text { No. of systematic Example of quotes } \\
\text { reviews and meta- } \\
\text { analyses }\end{array}$ \\
\cline { 2 - 3 } & $\begin{array}{l}\text { No. of No. of } \\
\text { barriers facilitators }\end{array}$ \\
\hline
\end{tabular}

\section{Factors related to hospital at home $(\mathrm{HBH})$ characteristics}

1.1 Characteristics of innovation

1.2 Patient empowerment

2. Individual factors: knowledge, attitude, and socio-demographic characteristics

2.1 Confidence in $\mathrm{HBH}$ developer or vendor

2.2 Autonomy

2.3 Sociodemographic characteristics

\section{External factors: human environment}

3.1 Patient and health professional interaction 1
Individual's home situation, social support networks [55]. Nursing care which is only available for the last 2 weeks of life [24].

Patient and carer education for the recognition and management of acute exacerbation of chronic obstructive pulmonary disease [23]. Self-management education provided at home [49].

Patients refused $\mathrm{HBH}$ due to lack of confidence and were admitted to hospital [52]

Differences were reported for patients' preferred place of care, with each group of patients preferring care at home [51].

Strong evidence that patients aged 75 and over may be safely included in early supported discharge (ESD) and hospital at home (HAH) schemes. Most patients hospitalized with acute exacerbation of chronic obstructive pulmonary disease are elderly [23].

Miscommunication in teaching the parents [50].

\section{External factors: organizational environment}

4.1 Internal environment

4.1.1 Characteristics of the structure of work

4.1.1.1 Practice size

4.1.1.2 Workforce issues (shortage, retention)

\subsubsection{Nature of work}

4.1.2.1 Work flexibility

\subsubsection{Skills (staff)}

4.1.3.1 Skill mix

4.1.3.2 Multidisciplinary collaboration
4.1.4.1 Material resources (access to information and communication technology)

4.1.4.2 Human resources (information technology (IT) support, other)

\subsubsection{Resources}

(IT) support, other)

Evening and night cover was provided by a direct line to medical chest unit or provided by district nurses [26].

Nursing care available for $24 \mathrm{~h}$ if required [25].

Lack of access to 24-h care [25].

The service was co-ordinated by a nurse $[12,20,22,24-26,52]$; rehabilitation services were coordinated with social care [51]. Nurses with respiratory experience $[12,23]$ or experience in delivering $\mathrm{HAH}$ treatment [23].

Nurse and medical team (including a physician) [53. Specialist and dedicated nurses, specialist physicians, social worker, dietitian, physiotherapist, occupational therapist (OT), speech therapist, and volunteers $[22,51]$. Hospital outreach team, a mix of outreach and community staff, general practitioner, community nursing staff, physiotherapist, OT, social worker, counselor, speech therapist, cultural link worker $[25,52]$.
Telephone support $[23,49]$, oxygen therapy, nebulised bronchodilators, intravenous antibiotics, and steroids [23].

Lab values and ECGs done at home, radiographs and echocardiograms at hospital [49].

Staff reported that the service was better staffed than usual after care services [51]. Nurses reported that additional help should have been provided for caregivers looking after the participants and for night nursing [24]. barrier. Only factors related to patients were underlined: confidence in $\mathrm{HBH}$ developer or provider, autonomy (health empowerment), and socio-demographical characteristics. The patient's preferred place of care was the home, which facilitated the implementation of the $\mathrm{HBH}$ model [51], with strong evidence on the applicability and safety of the $\mathrm{HBH}$ model to the predominant characteristics of patients, aged 75 years or older [23]. Only one individual factor was identified as a barrier in $\mathrm{HBH}$, namely lack of confidence in $\mathrm{HBH}$ developer, because a small proportion of patients refused $\mathrm{HBH}$ and were admitted to conventional hospital [52]. 


\section{External factors: human environment}

External factors related to the human environment refer to the clinical team and their interactions with patients. The only factor identified in this category as a barrier for $\mathrm{HBH}$ in children was the miscommunication in teaching parents that affected the patient and health professional interaction [50].

\section{External factors: internal organizational environment}

Most of the elements reported in the reviews belong to this category, with 27 considered as facilitators and 2 as barriers.

The two most common facilitating factors identified were skill mix [12, 20, 22-26, 49, 51-53] and multidisciplinary collaboration $[20,22-26,49,51-53]$. About skill mix, the HBH model coordinated by nurses was seen as a facilitator [12, 20, 22, 24-26, 52] as well as rehabilitation services that were coordinated with social care [51]. In relation to nursing skills, HBH was facilitated when nurses were specialists $[49,51]$ or had experience with respiratory care [12, 23, 25], administration of antineoplastic drugs [53], palliative care [24], and $\mathrm{HBH}$ [23].

Multidisciplinary teams are a key facilitator in $\mathrm{HBH}$ models. Such teams could include nurses and medical teams (including specialist physicians and family physicians) [20, 22-25, 49, 51-53], social care workers, dietitians, physiotherapists, occupational therapists, speech therapists, pharmacists, psychologists $[22-26,49,51$, $52]$, volunteers $[22,25,51]$, palliative care consultants, nutritionists [24], hospital outreach team, community staff, counselor, and cultural link worker [25, 52].

Characteristics of the structure of work related to practice size [25] and nature of work, specifically the work flexibility for evening and night cover of nursing team [26], were identified as facilitators for $\mathrm{HBH}$. Likewise, provision of material resources (for example, telephone support [23, 25, 49], oxygen therapy, nebulised bronchodilators, intravenous antibiotics and steroids [23], laboratory tests, and electrocardiogram done at home [49]) was also seen as potential facilitators for $\mathrm{HBH}$ model implementation.

Two perceived barriers were workforce issues related to reduce nursing staff, especially the night staff, and lack of human resources for 24-h care. The heterogeneous profile of the included patients also required training for nurses, especially for daily home visits. Team composition of the $\mathrm{HBH}$ models was heterogeneous and there was a lack of data on who was responsible for each care delivery [24].

\section{Discussion}

\section{Summary of main results}

This systematic review of reviews provides a mapping of the indicators (positive, negative, or neutral indicators) of the $\mathrm{HBH}$ model, categorized by the dimensions of nursing care, as well as the factors identified as barriers or facilitators to its implementation.
With respect to the indicators of $\mathrm{HBH}$ model, our review corroborates the positive clinical and economic indicators previously documented since 1998. The main contribution of this review is to map these indicators according to the NCPF, which provides a structured approach to analyze how the HBH model works to produce the identified outcomes.

Moreover, our work provides a first review of the factors that could facilitate or hinder the implementation of the HBH model. Our results show that 13 implementation factors influenced the implementation of the $\mathrm{HBH}$ model. Among them, the multidisciplinary collaboration and skill mix of professionals inherent to the internal organizational factors were identified as the main facilitators. Conversely, some characteristics of the HBH model, specifically related to the clinical criteria of eligibility and social situation of patients were identified as barriers to implementation.

Based on the AMSTAR2, the overall quality of the included reviews was good, with a number of high and moderate quality reviews, and only two reviews with important methodological limitations. The lack of systematization of data in these reviews led to a lower quality score on the AMSTAR2 scale because we lacked information for assessing the risk of bias. This result may be related to clinical trials that still lack detailed information on the methods used and present methodological flaws that compromise their internal validity $[56,57]$.

\section{Discussion of results with respect to the NCPF}

In relation to the first function of the NCPF (acquiring, deploying, and maintaining nursing resources), almost all reviews outlined outcomes linked to a dimension of the NCPF called economic sustainability [36]. The positive indicator related to the potential of $\mathrm{HBH}$ model to reduce healthcare spending does not directly reflect the total cost of the resources used, including the direct costs for the health sector and the indirect costs related to the impact on families and society, which makes it difficult to assess the cost-effectiveness [12, 20, 22, 23, $26,44,49-52,55]$. Two reviews mentioned the importance of service continuity offered in the $\mathrm{HBH}$ model since the variations in the way the service is delivered may also account for differences in cost, specifically in HBH schemes that did not provide 24-h care [22, 51]. Regarding the cost of readmission, Echevarria et al. [23] identified conceptual confusion highlighting the need for further detail on this event for patients returning to the hospital during $\mathrm{HBH}$ and whether those patients are readmitted at home during the follow-up period.

With respect to the second NCPF function, nursing processes and professional satisfaction were highlighted in the transformation of nursing resources into nursing services. This function captures the benefits of nurse coordinating care in the $\mathrm{HBH}$ model for better patient management, 
particularly with respect to education including selfmanagement $[22,49,55]$. Another review confirmed the importance of patient/family involvement in self-care [23].

Although the HBH model is considered satisfactory for patients in the view of the professionals involved in hospital care, the perceptions of health care providers need to be explored, especially the professional satisfaction related to the work environment characteristics (perceived autonomy, role tension, collaboration). One review highlights that professional satisfaction may determine the potential for adoption of the HBH model and its effective implementation as an alternative hospital model inserted in the existing primary care services [25].

In the third function of the NCPF, the indicators concern the joint contribution of nursing and other systems aimed at the production of changes in patients' conditions. The environment was associated with positive indicators on patient quality of life $[49,50]$ and satisfaction of patients and their families [25, 50-53]. In these studies, the $\mathrm{HBH}$ environment was qualified as a family environment adapted to the individual that improved the trust relationship with health professionals, increased autonomy, and improved access to the service $[49,50]$. For patients and caregivers, home was considered as the preferred place for treatment and hospitalization. Although patients and family members are satisfied with the $\mathrm{HBH}$ model, it is still necessary to investigate in detail the participation and perception of family members associated with home hospitalization, particularly regarding the responsibility and the social aspects involved.

\section{Discussion of results with respect to the factors associated to implementation of the $\mathrm{HBH}$ model}

Given the considerable attention that the $\mathrm{HBH}$ model receives globally, it seemed important to identify the factors identified as facilitators or barriers to its implementation by healthcare organizations. The main findings of this review point out that several internal factors of the organizational environment and factors related to the characteristics of the $\mathrm{HBH}$ model influence the implementation of $\mathrm{HBH}$.

The combination of competency of health professionals [12, 20, 22-26, 49, 51-53] and multidisciplinary collaboration [20, 22-26, 49, 51-53] were seen as two important facilitators to the implementation of the $\mathrm{HBH}$ model in the included reviews.

Factors related to the characteristics of the HBH model that influence its implementation include innovation characteristics $[20,23,24,55]$ and patient empowerment $[23,25$, 49]. Some important features of the HBH model are coordinated care in each multidisciplinary team, 24-h provision with access to a physician, and a safe home environment.

In fact, the diversity of $\mathrm{HBH}$ schemes organized according to the national legislation and health systems of the countries was a barrier considered in two reviews $[23,25]$ because of the different structures of home hospitalization, including the variation of the size of healthcare teams, follow-up visits, and the provision of social and technological support.

The role of $\mathrm{HBH}$ model to support patient empowerment has been mentioned in three reviews [23, 25, 49]. In $\mathrm{HBH}$ model, healthcare professionals invested in managing patients and education of patients and families for self-care, supporting the idea of a user-centered approach promoted by the level of care provided and intensity of contact with healthcare professionals.

In addition, the support of technology for management and communication among the professionals of the multidisciplinary team $[23,25,49]$ and clinical support of $\mathrm{HBH}$ patients $[23,49]$ were also identified in some reviews, albeit less frequently. Although technological resources were a facilitator in the implementation of the $\mathrm{HBH}$ model, only a few studies highlighted the need for accessibility to mobile technologies such as telephones and diagnostic equipment.

\section{Agreements and disagreements with other systematic reviews}

Our systematic review of reviews focused on bringing together the scientific evidence on the HBH model published over the last two decades.

We have identified a systematic review of systematic reviews by Conley et al. [58] through our research strategy. Unlike our systematic review, Conley et al. [58] did not focus solely on $\mathrm{HBH}$ but examined systematic reviews of alternative management strategies to hospital inpatient unit, including outpatient management, rapid diagnosis units, observation unit, and HBH. Of the 25 systematic reviews selected by Conley et al. [58], only six reviews were related to $\mathrm{HBH}$ and of these, four systematic reviews [12, $20,49,51]$ were included in our review. The two others were excluded because they were not systematic reviews.

In relation to clinical outcomes, Conley et al.'s review [58] found positive indicators on cost of resources and patient and caregiver satisfaction for multiple conditions, and neutral indicators on hospital readmission and mortality in HBH management compared with conventional inpatient admission across many acute medical conditions (including heart failure and COPD exacerbations, cellulitis, community-acquired pneumonia, pulmonary embolism, and stroke). They also showed a critical need to determine optimal patient eligibility, and date riskstratifying algorithms require further evaluation and validation. Diverging from our results, Conley et al. [58] did not find any positive indicators related to additional patient outcomes (functional ability, quality of life, or disease-specific outcomes) in $\mathrm{HBH}$. 


\section{Study strengths and limitations}

This systematic review of reviews has many strengths. Firstly, a comprehensive search strategy was developed and implemented in partnership with a health information specialist. Secondly, findings that emerge from the analysis of reviews focus on the evaluation of the indicators of $\mathrm{HBH}$ models and the factors influencing their implementation in the form of a narrative synthesis, rather than from the analysis of individual studies. Third, the data extraction process was done with the use of the NCPF and a comprehensive grid of barriers and facilitators to implementation, which supported the organization and the analysis of findings. Moreover, most of the reviews included in this review had a good quality according to the AMSTAR2. However, AMST AR2 is not intended for the assessment of mixed methods systematic reviews that include qualitative studies, this being one of the limitations of our study.

Some limitations have also been identified. We were limited by the information provided by the reviews authors, which also highlighted a great heterogeneity of $\mathrm{HBH}$ schemes in terms of definition, population, interventions, and variety of outcomes. It must be emphasized that some indicators may be overestimated in this review because they come from the same primary studies that have been compiled in different systematic reviews. Despite these limitations, our synthesis contributes to the knowledge base on the $\mathrm{HBH}$ model, the facilitating and limiting factors of its implementation, together with the indicators of this model of care in the organization of services, as well as at the clinical, economic, political, and social levels.

\section{Conclusions}

Many systematic reviews have been published on homebased hospitalization, indicating the growing interest in evaluating this intermediary resource on the health services network, specifically the impact on patients, their families, and society.

Our findings provide a mapping of the indicators of the $\mathrm{HBH}$ model, categorized by the dimensions of nursing care, as well as the factors identified as barriers or facilitators to its implementation.

The indicators according to the NCPF identified in studies on the implementation of this care model totaled 26 indicators related to nursing care in relation to the cost of resources, management of problems and symptoms, comfort and quality of life, cognitive and psychosocial functional capacity, patient and caregiver satisfaction, hospital mortality, readmissions, and length of stay. Among these, six new indicators were discovered in the analysis of the indicators of the $\mathrm{HBH}$ model, namely use of hospital beds, new emergency consultations, and use of healthcare services as indicators of resources of cost, and bowel complications, caregiver satisfaction, and survival time as indicators of change in the patient's condition. These new indicators provide additional information in the evaluation of the total cost of resources used in the $\mathrm{HBH}$ model, including direct costs and indirect costs, and in the evaluation of the production of changes in patients' conditions based on the joint contribution of nursing and other linked systems in this care model. However, it is still necessary to investigate in detail the cost-effectiveness of the $\mathrm{HBH}$ model and the participation and perception of patients and family members associated with home hospitalization.

Regarding the factors that influenced the implementation of the $\mathrm{HBH}$ model by health organizations, our review identified 13 factors related mainly to internal organizational factors (multidisciplinary collaboration and skill mix of professionals). Two of these facilitators were seen as important for the implementation of the $\mathrm{HBH}$ model in the included reviews, specifically the combination of competence of health professionals and the coordinated care in each multidisciplinary team in home hospitalization. The main barriers were linked to characteristics of the $\mathrm{HBH}$, specifically eligibility criteria (complexity and social situation of the patient) because of the different structures of home hospitalization organized according to the national legislation and health systems of the countries. Since the multidisciplinary collaboration and the skill mix of professionals were found as internal organizational facilitating factors, the limited and transitory approach to the use of technologies in the implementation of the $\mathrm{HBH}$ model presented in the systematic reviews analyzed call for further investigation.

We suggest that the use of technologies in the implementation of the $\mathrm{HBH}$ model must be addressed in detail with respect to continuity of care and interprofessional collaborations centered on patients and their families, according to the nature of the experience, interests and needs to define the information, and communication technologies interventions necessary for the $\mathrm{HBH}$ model.

Although only three reviews included qualitative studies [53-55], we have identified evidence that valued the description of the process of organizing this alternative delivery model to hospital care, highlighting the facilitators and barriers associated with the successful implementation and use of this model of care. Our review shows that the documented indicators are directly related to changes in patient condition and were identified in intermediary resources such as $\mathrm{HBH}$ inserted in the care and service trajectory with an impact on structure, process, and results, taking into account the influence of external and internal factors. However, evidence is lacking regarding many outcomes, notably safety and burden on family/informal caregivers. 


\section{Appendix 1}

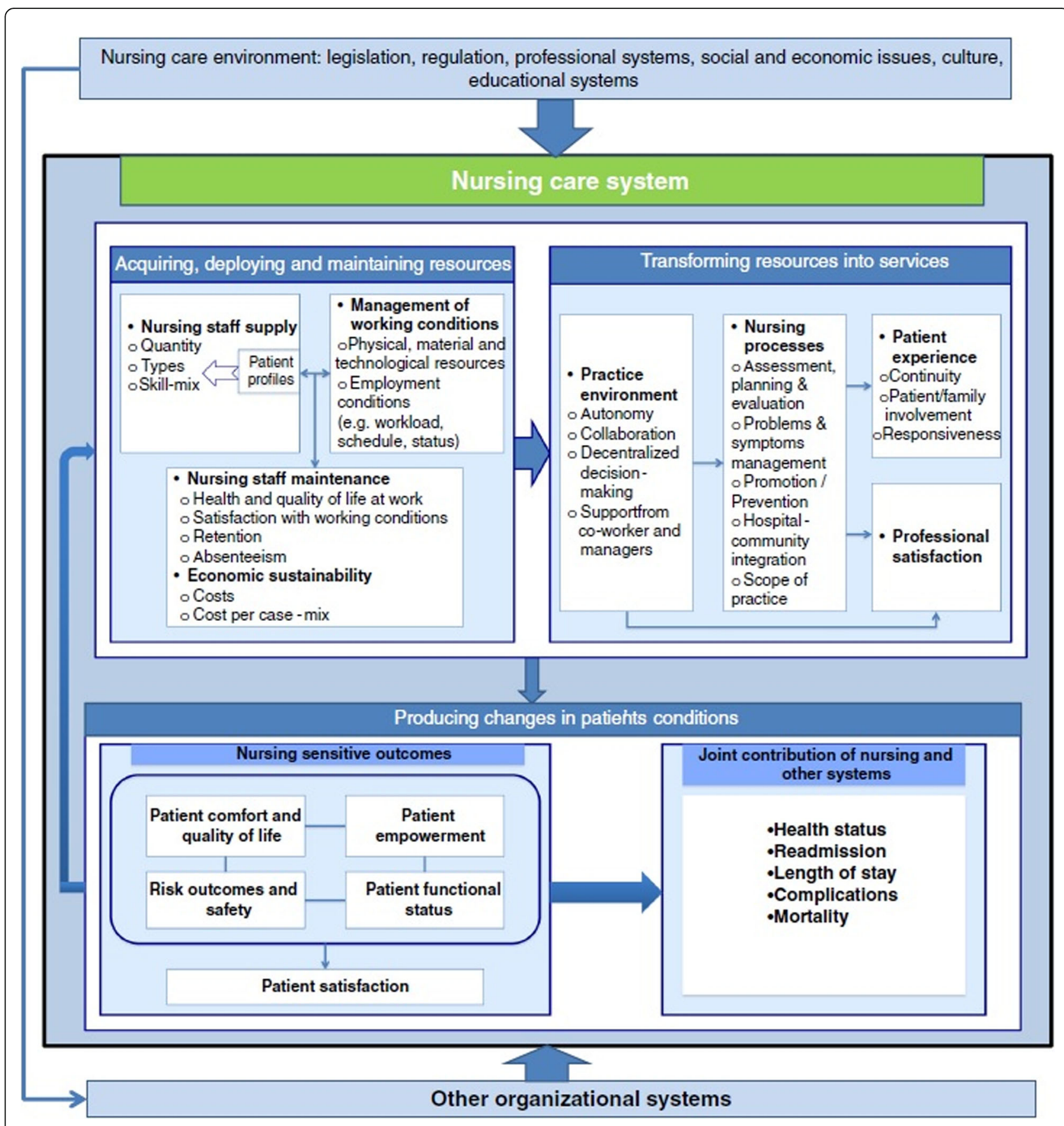

Fig. 3 The nursing care performance framework by Dubois* [36]. Legend: asterisk indicates that use and reproduction of this figure was authorized by the author 


\section{Appendix 2. Search strategies}

Table 5 Medline (OVID)

\begin{tabular}{|c|c|c|}
\hline Search & Query & Results \\
\hline$\# 1$ & (hospital adj2 home).tw. & 3707 \\
\hline \#2 & home based versus hospital based.tw. & 14 \\
\hline$\# 3$ & home hospitalization.tw. & 133 \\
\hline$\# 4$ & exp Home Care Services/ & 44,262 \\
\hline \#5 & exp Hospitalization/ & 205,749 \\
\hline \#6 & 4 and 5 & 4826 \\
\hline \#7 & 1 or 2 or 3 or 6 & 8068 \\
\hline$\# 8$ & Meta-Analysis as Topic/ & 16,136 \\
\hline$\# 9$ & meta analy\$.tw. & 125,472 \\
\hline$\# 10$ & metaanaly\$.tw. & 1822 \\
\hline \#11 & Meta-Analysis/ & 87,336 \\
\hline$\# 12$ & (systematic adj (review\$1 or overview\$1)).tw. & 119,387 \\
\hline$\# 13$ & exp Review Literature as Topic/ & 9820 \\
\hline$\# 14$ & or/8-13 & 227,170 \\
\hline \#15 & cochrane.ab. & 60,038 \\
\hline \#16 & embase.ab. & 63,584 \\
\hline$\# 17$ & (psychlit or psyclit).ab. & 909 \\
\hline \#18 & (psychinfo or psycinfo).ab. & 22,332 \\
\hline \#19 & (cinahl or cinhal).ab. & 20,527 \\
\hline$\# 20$ & science citation index.ab. & 2751 \\
\hline$\# 21$ & bids.ab. & 451 \\
\hline \#22 & cancerlit.ab. & 623 \\
\hline \#23 & or/15-22 & 104,043 \\
\hline$\# 24$ & reference list $\$ . a b$. & 15,147 \\
\hline$\# 25$ & bibliograph\$.ab. & 15,647 \\
\hline \#26 & hand-search\$.ab. & 5844 \\
\hline$\# 27$ & relevant journals.ab. & 1042 \\
\hline$\# 28$ & manual search\$.ab. & 3685 \\
\hline \#29 & or/24-28 & 37,062 \\
\hline$\# 30$ & selection criteria.ab. & 26,761 \\
\hline \#31 & data extraction.ab. & 16,097 \\
\hline \#32 & 30 or 31 & 40,796 \\
\hline \#33 & Review/ & $2,369,814$ \\
\hline \#34 & 32 and 33 & 27,208 \\
\hline \#35 & Comment/ & 713,540 \\
\hline \#36 & Letter/ & 983,939 \\
\hline \#37 & Editorial/ & 455,744 \\
\hline \#38 & animal/ & $6,190,908$ \\
\hline \#39 & human/ & $17,017,485$ \\
\hline \#40 & 38 not (38 and 39) & $4,414,780$ \\
\hline \#41 & or/35-37,40 & $5,976,817$ \\
\hline \#42 & 14 or 23 or 29 or 34 & 273,439 \\
\hline \#43 & 42 not 41 & 259,332 \\
\hline$\# 44$ & 7 and 43 & 239 \\
\hline
\end{tabular}

Table 6 CINAHL Plus with Full Text

\begin{tabular}{lll}
\hline Search & Query & Results \\
\hline S11 & S5 AND S10 & $\mathbf{3 0 6}$ \\
S10 & S6 OR S7 OR S8 OR S9 & 126, \\
& & 202 \\
S9 & systematic N2 (review or overview) & 92,36 \\
S8 & (MH "Literature Review+") & 62,327 \\
S7 & Meta analys* OR Metaanaly* & 56,065 \\
S6 & (MH "Meta Analysis") & 31,89 \\
S5 & S1 OR S2 OR S3 OR S4 & 7688 \\
S4 & (MH "Home Health Care") AND (MH "Hospitalization") & 590 \\
S3 & TI Home hospitalization OR AB Home hospitalization & 3477 \\
S2 & TI Home-based versus hospital-based OR AB Home-based & 24 \\
& versus hospital-based & \\
S1 & TI hospital N2 home OR AB hospital N2 home & 4222 \\
\hline
\end{tabular}


Table 7 Embase

\begin{tabular}{|c|c|c|}
\hline Search & Query & Results \\
\hline$\# 40$ & \# 32 OR \#39 & 361 \\
\hline \#39 & \#33 OR \#34 OR \#35 OR \#38 & 9305 \\
\hline \#38 & \#36 AND \#37 & 4243 \\
\hline \#37 & 'hospitalization'/de & 302,681 \\
\hline \#36 & 'home care'/exp & 66,443 \\
\hline \#35 & 'home-based versus hospital based'ab,ti & 18 \\
\hline \#34 & 'home hospitalization':ab,ti & 199 \\
\hline \#33 & ('hospital' NEAR/2 'home'):ab,ti & 5258 \\
\hline \#32 & \#31 NOT \#30 & 372,637 \\
\hline \#31 & \#4 OR \#13 OR \#19 OR \#24 & 387,258 \\
\hline \#30 & \#25 OR \#26 OR \#29 & $\begin{array}{l}2,985 \\
597\end{array}$ \\
\hline \#29 & \#27 NOT (59 AND \#28) & $\begin{array}{l}1,394 \\
722\end{array}$ \\
\hline \#28 & 'human'/de & $\begin{array}{l}19,205 \\
255\end{array}$ \\
\hline \#27 & 'animal'/de & $\begin{array}{l}1,829 \\
542\end{array}$ \\
\hline \#26 & 'letter':it OR 'letter'/de & $\begin{array}{l}1,013 \\
470\end{array}$ \\
\hline \#25 & 'editorial':it OR 'editorial'/de & 602,895 \\
\hline \#24 & \#22 AND \#23 & 24,469 \\
\hline \#23 & 'review'/de OR review:it & $\begin{array}{l}2,445 \\
565\end{array}$ \\
\hline \#22 & \#20 OR \#21 & 48,611 \\
\hline \#21 & 'selection criteria':ab & 31,177 \\
\hline \#20 & 'data extraction':ab & 19,337 \\
\hline \#19 & $\# 14$ Or \#15 OR \#16 OR \#17 OR \#18 & 42,960 \\
\hline \#18 & 'relevant journals':ab & 1210 \\
\hline \#17 & 'manual search*':ab & 4282 \\
\hline \#16 & 'hand-search*'ab & 6862 \\
\hline \#15 & 'bibliograph*':ab & 19,517 \\
\hline \#14 & 'reference lists':ab & 15,852 \\
\hline \#13 & \#5 OR \#6 OR \#7 OR \#8 OR \#9 Or \#10 OR \#11 OR \#12 & 123,233 \\
\hline$\# 12$ & bids:ab & 564 \\
\hline \#11 & 'science citation index':ab & 3113 \\
\hline \#10 & cinahl:ab OR cinalh:ab & 22,329 \\
\hline \#9 & psychinfo:ab OR psycinfo:ab & 19,854 \\
\hline \#8 & psychlit:ab OR psyclit:ab & 977 \\
\hline \#7 & embase:ab & 78,585 \\
\hline \#6 & cochrane:ab & 76,068 \\
\hline \#5 & cancerlit:ab & 708 \\
\hline \#4 & \#1 OR \#2 OR \#3 & 340,912 \\
\hline \#3 & (systematic NEAR/1 (review* OR overview*)):ab,ti & 143,580 \\
\hline \#2 & ((meta NEAR/1 analy*):ti,ab) OR metaanalys*:ti,ab & 162,940 \\
\hline$\# 1$ & $\begin{array}{l}\text { 'systematic review'/de OR 'meta analysis'/exp OR 'meta } \\
\text { analysis (topic)'/de }\end{array}$ & 272,499 \\
\hline
\end{tabular}

\section{Table 8 Cochrane}

\begin{tabular}{lll}
\hline Search & Query & Results \\
\hline$\# 1$ & hospital near/2 home:ti,ab,kw & 1004 \\
\#2 & home hospitalization:ti,ab,kw & 1880 \\
\#3 & Home-based versus hospital-based :ti,ab,kw & 60 \\
\#4 & $\# 1$ or \#2 or \#3 & $\mathbf{2 6 5 0}$ \\
& Cochrane Database of Systematic Reviews (CDSR) & $\mathbf{1 1 7}$ \\
& Database of Abstracts of Reviews of Effects (DARE) & $\mathbf{4 6}$ \\
\hline
\end{tabular}




\section{Appendix 3}

Table 9 Preferred Reporting Items for Systematic review and Meta-Analysis extension for Network Meta-Analyses (PRISMA-NMA) checklist [31]

\begin{tabular}{lll}
\hline Section/topic & $\# \quad$ Checklist item \\
\hline $\begin{array}{l}\text { Title } \\
\text { Title }\end{array}$ & $\begin{array}{l}\text { Identify the report as a systematic review incorporating a network meta-analysis } \\
\text { (or related form of meta-analysis). }\end{array}$ \\
Abstract & \\
Structured summary $2 \quad \begin{array}{l}\text { Provide a structured summary including, as applicable: Background: main } \\
\text { objectives. Methods: data sources; study eligibility criteria, participants, and } \\
\text { interventions; study appraisal; and synthesis methods, such as network meta- } \\
\text { analysis. Results: number of studies and participants identified; summary } \\
\text { estimates with corresponding confidence/credible intervals; treatment rankings } \\
\text { may also be discussed. Authors may choose to summarize pairwise comparisons } \\
\text { against a chosen treatment included in their analyses for brevity. Discussion/ } \\
\text { conclusions: limitations; conclusions and implications of findings. Other: primary } \\
\text { source of funding; systematic review registration number with registry name. }\end{array}$
\end{tabular}

\section{Introduction}

Rationale

Objectives

\section{Methods}

Protocol and registration

Eligibility criteria

Information sources

Search

Study selection

Data collection process

Data items

Geometry of the network

Risk of bias in individual studies

Summary measures

Planned methods of analysis

Assessment of inconsistency
3 Describe the rationale for the review in the context of what is already known, including mention of why a network meta-analysis has been conducted.

4 Provide an explicit statement of questions being addressed, with reference to participants, interventions, comparisons, outcomes, and study design (PICOS).

5 Indicate whether a review protocol exists and if and where it can be accessed (e.g., Web address); and, if available, provide registration information, including registration number.

6 Specify study characteristics (e.g., PICOS, length of follow-up) and report characteristics (e.g., years considered, language, publication status) used as criteria for eligibility, giving rationale. Clearly describe eligible treatments included in the treatment network and note whether any have been clustered or merged into the same node (with justification).

7 Describe all information sources (e.g., databases with dates of coverage, contact with study authors to identify additional studies) in the search and date last searched.

8 Present full electronic search strategy for at least one database, including any limits used, such that it could be repeated.

9 State the process for selecting studies (i.e., screening, eligibility, included in systematic review, and, if applicable, included in the meta-analysis).

10 Describe method of data extraction from reports (e.g., piloted forms, independently, in duplicate) and any processes for obtaining and confirming data from investigators.

11 List and define all variables for which data were sought (e.g., PICOS, funding sources) and any assumptions and simplifications made.

S1 Describe methods used to explore the geometry of the treatment network under study and potential biases related to it. This should include how the evidence base has been graphically summarized for presentation, and what characteristics were compiled and used to describe the evidence base to readers.

12 Describe methods used for assessing risk of bias of individual studies (including specification of whether this was done at the study or outcome level), and how this information is to be used in any data synthesis.

13 State the principal summary measures (e.g., risk ratio, difference in means). Also describe the use of additional summary measures assessed, such as treatment rankings and surface under the cumulative ranking curve (SUCRA) values, as well as modified approaches used to present summary findings from meta-analyses.

14 Describe the methods of handling data and combining results of studies for each network meta-analysis. This should include, but not be limited to: handling of multigroup trial, selection of variance structure, selection of prior distributions in Bayesian analyses, and assessment of model fit.

S2 Describe the statistical methods used to evaluate the agreement of direct and indirect evidence in the treatment network(s) studied. Describe efforts taken to address its presence when found.
This is not applicable

This is not applicable

This is not applicable applicable 
Table 9 Preferred Reporting Items for Systematic review and Meta-Analysis extension for Network Meta-Analyses (PRISMA-NMA) checklist [31] (Continued)

\begin{tabular}{lrl}
\hline Section/topic & Checklist item \\
\hline $\begin{array}{l}\text { Risk of bias across } \\
\text { studies }\end{array}$ & $15 \begin{array}{l}\text { Specify any assessment of risk of bias that may affect the cumulative evidence } \\
\text { (e.g., publication bias, selective reporting within studies). }\end{array}$ \\
Additional analyses 16 Describe methods of additional analyses if done, indicating which were \\
prespecified. This may include, but not be limited to, the following: sensitivity or \\
subgroup analyses; meta-regression analyses; alternative formulations of the \\
treatment network, and use of alternative prior distributions for Bayesian analyses \\
(if applicable).
\end{tabular}

\section{Results}

Study selection

Presentation of network structure

Summary of network geometry

Study characteristics

Risk of bias within studies

Results of individua studies

Synthesis of results

Exploration for inconsistency

Risk of bias across studies

Results of additional analyses

\section{Discussion}

Summary of evidence

Limitations

Conclusions

\section{Funding}

Funding
17 Give numbers of studies screened, assessed for eligibility, and included in the review, with reasons for exclusions at each stage, ideally with a flow diagram.

Provide a network graph of the included studies to enable visualization of the geometry of the treatment network.

S3 Provide a network graph of the included studies to enable visualization of the geometry of the treatment network.

S4 Provide a brief overview of characteristics of the treatment network. This may include commentary on the abundance of trials and randomized patients for the different interventions and pairwise comparisons in the network, gaps of evidence in the treatment network, and potential biases reflected by the network structure.

18 For each study, present characteristics for which data were extracted (e.g., study size, PICOS, follow-up period) and provide the citations.

19 Present data on risk of bias of each study and, if available, any outcome level assessment.

20 For all outcomes considered (benefits or harms), present, for each study: (1) simple summary data for each intervention group, and (2) effect estimates and confidence intervals. Modified approaches may be needed to deal with information from larger networks.

21 Present results of each meta-analysis done, including confidence/credible intervals. In larger networks, authors may focus on comparisons versus a particular comparator (e.g., placebo or standard care), with full findings presented in an appendix. League tables and forest plots may be considered to summarize pairwise comparisons. If additional summary measures were explored (such as treatment rankings), these should also be presented.

S5 Describe results from investigations of inconsistency. This may include such information as measures of model fit to compare consistency and inconsistency models, $P$ values from statistical tests, or summary of inconsistency estimates from different parts of the treatment network.

22 Present results of any assessment of risk of bias across studies for the evidence base being studied.

23 Give results of additional analyses, if done (e.g., sensitivity or subgroup analyses, meta-regression analyses, alternative network geometries studied, and alternative choice of prior distributions for Bayesian analyses)

24 Summarize the main findings, including the strength of evidence for each main outcome; consider their relevance to key groups (e.g., health care providers, researchers, and policymakers).

25 Discuss limitations at study and outcome level (e.g. risk of bias), and at review level (e.g., incomplete retrieval of identified research, reporting bias). Comment on the validity of the assumptions, such as transitivity and consistency. Comment on any concerns regarding network geometry (e.g., avoidance of certain comparisons)

26 Provide a general interpretation of the results in the context of other evidence and implications for future research.
Reported

on page \#

This is not

applicable

This is not applicable applicable

9-11, 76

This is not applicable

This is not applicable

27 Describe sources of funding for the systematic review and other support (e.g., supply of data); role of funders for the 43 systematic review. This should also include information regarding whether funding has been received from manufacturers of treatments in the network and/or whether some of the authors are content experts with professional conflicts of interest that could affect use of treatments in the network. 


\section{Appendix 4}

Table 10 Primary studies of $\mathrm{HBH}$ included in systematic reviews and meta-analyses

\begin{tabular}{|c|c|c|c|c|c|c|c|c|c|c|c|c|c|c|c|}
\hline \multirow[t]{2}{*}{ Primary studies } & \multicolumn{15}{|c|}{ Systematic reviews and meta-analyses } \\
\hline & [53] & [54] & [22] & [55] & [24] & [25] & [23] & [49] & {$[20]$} & {$[12]$} & {$[50]$} & [51] & {$[52]$} & [26] & [44] \\
\hline
\end{tabular}

Cocquyt, 2016

Dey, 2016

Karlsson, 2016

$x$

Touati, 2016

Lal, 2015

Crisp, 2014

Ince, 2014

García-Soleto, 2013

Lasalle, 2016

Lau, 2013

Tibaldi, 2013

Vianello, 2013

Lüthi, 2012

Utens, 2012

Andrei, 2011

Aujesky 2011

Crilly, 2011

Talcott 2011

Meenaghan, 2010

Otero, 2010

Frick, 2009

Leff, 2009

Mendoza, 2009

Rodríguez-Cerrillo, 2009

Tibaldi, 2009

Hall, 2008

Patel, 2008

Rada, 2008

Ricauda, 2008

Ricauda, 2008

Brumley, 2007

Nissen, 2007

Caplan, 2006

Stevens, 2006

Vergnenègre, 2006

Carratalà, 2005

Corwin, 2005

Diaz Lobato, 2005

Harris, 2005

Leff, 2005

Richards, 2005

Rodríguez-Cerrillo, 2005

x

x

$\mathrm{x}$

x

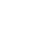

$x$

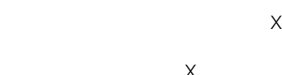

$x$

$x$

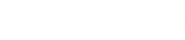


Table 10 Primary studies of HBH included in systematic reviews and meta-analyses (Continued)

\begin{tabular}{|c|c|c|c|c|c|c|c|c|c|c|c|c|c|c|c|c|}
\hline \multirow[t]{2}{*}{ Primary studies } & \multicolumn{15}{|c|}{ Systematic reviews and meta-analyses } & \multirow[t]{2}{*}{ Total } \\
\hline & [53] & [54] & {$[22]$} & [55] & {$[24]$} & [25] & [23] & [49] & [20] & {$[12]$} & [50] & {$[51]$} & [52] & [26] & [44] & \\
\hline Askim, 2004 & & & $x$ & & & & & & & & & $x$ & & & & 2 \\
\hline Booth, 2004 & & & $x$ & & & & & & & & & $x$ & & & & 2 \\
\hline Cunliffe, 2004 & & & $x$ & & & & & & & & & $x$ & & & & 2 \\
\hline Donnelly, 2004 & & & $x$ & & & & & & & & & $x$ & & & & 2 \\
\hline Ricauda, 2004 & & & & & & $x$ & & & & & & & $x$ & & & 2 \\
\hline Tibaldi, 2004 & & & & & & $x$ & & & $x$ & & & & $x$ & & & 3 \\
\hline Anderson, 2003 & $x$ & & & & & & & & & & & & & & & 1 \\
\hline de Zuazu, 2003 & & & & & & & & $x$ & & & & & & & & 1 \\
\hline Hernandez, 2003 & & $x$ & & & & & & & $x$ & $x$ & & & & $x$ & & 4 \\
\hline Virally, 2003 & $x$ & & & & & & & & & & & & & & & 1 \\
\hline Bautz-Holter, 2002 & & & $x$ & & & & & & & & & $x$ & & & & 2 \\
\hline Corrie, 2013 & $x$ & & & & & & & & & & & & & & & 1 \\
\hline Crotty, 2002 & & & $x$ & & & & & & & & & $x$ & & & & 2 \\
\hline Miano, 2002 & & & & & & & & & & & $x$ & & & & & 1 \\
\hline Ojoo, 2002 & & & $x$ & & & & $x$ & & $x$ & $x$ & & $x$ & & $x$ & & 6 \\
\hline Remonnay, 2002 & $x$ & & & & & & & & & & & & & & & 1 \\
\hline Farrero, 2001 & & $x$ & & & & & & & & & & & & & & 1 \\
\hline Nicholson, 2001 & & & & & & $x$ & & & $x$ & $x$ & & & $x$ & $x$ & & 5 \\
\hline Suwenwela, 2001 & & & $x$ & & & & & & & & & $x$ & & & & 2 \\
\hline Anderson, 2000 & & & $x$ & & & & & & & & & $x$ & & & & 2 \\
\hline Bechich, 2000 & & & & & & & & $x$ & & & & & & & & 1 \\
\hline Borras, 2001 & $x$ & & & & & & & & & & & & & & & 1 \\
\hline Cotton, 2000 & & & $x$ & & & & $x$ & & $x$ & $x$ & & $x$ & & $x$ & & 6 \\
\hline Davies, 2000 & & & & & & $x$ & $x$ & & $x$ & $x$ & & & $x$ & $x$ & & 6 \\
\hline Grande, 2000 & & & & & $x$ & & & & & & & & & & & 1 \\
\hline Indredavik, 2000 & & & $x$ & & & & & & & & & $x$ & & & & 2 \\
\hline Jordhøy, 2000 & & & & & $x$ & & & & & & & & & & & 1 \\
\hline Kalra, 2000 & & & & $x$ & & $x$ & & & & & & & $x$ & & & 3 \\
\hline King, 2000 & $x$ & & & & & & & & & & & & & & & 1 \\
\hline Mayo, 2000 & & & $x$ & & & & & & & & & $x$ & & & & 2 \\
\hline Palmer Hill, 2000 & & & $x$ & & & & & & & & & $x$ & & & & 2 \\
\hline Rischin, 2000 & $x$ & & & & & & & & & & & & & & & 1 \\
\hline Skwarska, 2000 & & & $x$ & & & & $x$ & & $x$ & $x$ & & $x$ & & $x$ & & 6 \\
\hline Caplan, 1999 & & & & & & $x$ & & & $x$ & & & & $x$ & & & 3 \\
\hline Wilson, 1999 & & & & & & $x$ & & & $x$ & & & & $x$ & & & 3 \\
\hline Richards, 1998 & & & $x$ & & & & & & $x$ & & & $x$ & & & & 3 \\
\hline Shepperd 1998 & & & $x$ & & & & & & $x$ & & & $x$ & & $x$ & & 4 \\
\hline Widén Holmqvist, 1998 & & & $x$ & & & & & & & & & $x$ & & & & 2 \\
\hline Holdsworth, 1997 & & & & & & & & & & & $x$ & & & & & 1 \\
\hline Rodgers, 1997 & & & $x$ & & & & & & & & & $x$ & & & & 2 \\
\hline Rudd, 1997 & & & $x$ & & & & & & & & & $x$ & & & & 2 \\
\hline Koopman, 1996 & & & & & & & & & $x$ & & & & & & & 1 \\
\hline Levine, 1996 & & & & & & & & & $x$ & & & & & & & 1 \\
\hline
\end{tabular}


Table 10 Primary studies of HBH included in systematic reviews and meta-analyses (Continued)

\begin{tabular}{|c|c|c|c|c|c|c|c|c|c|c|c|c|c|c|c|c|c|}
\hline \multirow{2}{*}{\multicolumn{2}{|c|}{ Primary studies }} & \multicolumn{15}{|c|}{ Systematic reviews and meta-analyses } & \multirow[t]{2}{*}{ Total } \\
\hline & & [53] & [54] & [22] & [55] & [24] & [25] & [23] & [49] & [20] & {$[12]$} & [50] & [51] & [52] & [26] & [44] & \\
\hline Close, 1995 & & & & & & & & & & & & $x$ & & & & & 1 \\
\hline Donald, 1995 & & & & $x$ & & & & & & & & & $x$ & & & $x$ & 3 \\
\hline Martin, 1994 & & & & $x$ & & & & & & & & & $x$ & & & $x$ & 3 \\
\hline Hughes, 1992 & & & & & & $x$ & & & & & & & & & & $x$ & 2 \\
\hline Melin, 1992 & & & & & & & & & & $x$ & & & & & & & 1 \\
\hline Payne, 1992 & & $x$ & & & & & & & & & & & & & & & 1 \\
\hline Lange, 1988 & & & & & & & & & & & & $x$ & & & & & 1 \\
\hline Adler, 1978 & & & & $x$ & & & & & & & & & $x$ & & & $x$ & 3 \\
\hline Hill, 1978 & & & & & & & & & & $x$ & & & & & & & 1 \\
\hline Ruckley, 1978 & & & & $x$ & & & & & & & & & $x$ & & & $x$ & 3 \\
\hline Mather, 1976 & & & & & & & & & & $x$ & & & & & & & 1 \\
\hline & Total & 17 & 4 & 32 & 15 & 4 & 16 & 7 & 5 & 26 & 8 & 5 & 26 & 10 & 7 & 5 & 187 \\
\hline
\end{tabular}




\section{Appendix 5}

Table 11 Excluded articles

Justification

Old version

\section{Commentary}

\section{No systematic review}

\section{Abstract}

\section{Analysis}

\section{Editorial}

References of excluded articles

Ram FSF, Wedzicha JA, Wright JJ, Greenstone M. Hospital at home for acute exacerbations of chronic obstructive pulmonary disease. Cochrane Database of Systematic Reviews 2003, Issue 4. Art. No.: CD003573. DOI: 10.1002/14651858.CD003573. Update [12]

Ram FSF, Wedzicha JA, Wright JJ, Greenstone M, Lasserson TJ. Hospital at home for acute exacerbations of chronic obstructive pulmonary disease. Cochrane Database System Rev 2009 (4). 20 OCT 2003. DOl: 10.1002/14651858.CD003573 Update [12]

Conley J, O'Brien CW, Leff BA, et al. Alternative strategies to inpatient hospitalization for acute medical conditions: a systematic review. JAMA Intern Med 2016;176:1693-702.doi:10.1001/ jamainternmed.2016.5974. Update [58]

Shepperd S, lliffe S. Hospital at home versus in-patient hospital care. Cochrane database of systematic reviews (online) 2001; null(3): CD000356. Update [22]

Shepperd S, lliffe S. Cochrane reviews. Hospital at home versus in-patient hospital care. Nursing Times. 2001;97(38):37. Update [22]

Parkes J, Shepperd S. Cochrane reviews. Discharge planning from hospital to home. Nursing Times. 2001;97(37):42. Update [22]

Shepperd S, lliffe S. Hospital at home versus in-patient hospital care. Cochrane Database of Systematic Reviews 2005, Issue 3. Art. No.: CD000356. DOI: 10.1002/14651858.CD000356.pub2. Update [22]

Langhorne P, Dennis M, Kalra L, Shepperd S, Wade D, Wolfe CDA. Services for helping acute stroke patients avoid hospital admission. Cochrane Database of Systematic Reviews 1999, Issue 3. Art. No. CD000444. DOI: 10.1002/14651858.CD000444.

Update [52]

Without author. 'Hospital at home' schemes are as safe as inpatient care for people with exacerbated chronic obstructive pulmonary disease (COPD). Evidence-Based Healthcare and Public Health. 2005;9(1):46-7.

Inpatient and hospital-at-home care: the same outcomes? Nursing Times, 104 (48), $29 ; 2008$.

Grad R. Review: hospital-at-home care for early discharge or admission avoidance does not improve health outcomes. ACP J Club. 2002 Jul-Aug;137:23.

Jacobs MB. Review: hospital-at-home care does not increase mortality or readmission rates in acute exacerbations of COPD. ACP Journal Club. 2004;140(3):59.

Reishtein JL. Review: hospital at home is as effective as inpatient care for mortality and hospital readmissions in patients with acute exacerbations of chronic obstructive pulmonary disease. Evidence Based Nursing. 2005;8(1):23.

Dickson HG. A meta-analysis of "hospital in the home". Comment. The Medical journal of Australia. 2013;198(4):195.

Mas MT, Santaeugènia S. Hospital-at-home in older patients: a scoping review on opportunities of developing comprehensive geriatric assessment based services. Revista Espanola de Geriatria y Gerontologia. 2015;50(1):26-34.

Messecar D. Review: admission-avoidance hospital-at-home decreases mortality at 6 months but does not differ from inpatient care for readmission. Evidence Based Nursing. 2009;12(3):82.

Mitre Cotta RM, Suárez-Varela MM, Llopis González A, Cotta Filho JS, Real ER, Días Ricós JA. Home hospitalization: background, current situation, and future prospects. Revista Panamericana de Salud Publica. 2001;10(1):45-55.

Goossens LMA, Vemer P, Rutten-Van Mölken MPMH. A systematic review of hospital-at-home care: cost savings are overestimated. Value in Health. 2012;15(7):A301.

Iliffe S, Shepperd S. What do we know about hospital at home? Lessons from international experience. Applied health economics and health policy. 2002;1(3):141-7.

McCurdy BR. Hospital-at-home programs for patients with acute exacerbations of chronic obstructive pulmonary disease (COPD): an evidence-based analysis. Ontario Health Technology Assessment Series. 2012;12(10):1-65.

Shepperd S, Cates C. Hospital at home in chronic obstructive pulmonary disease: is it a viable option? Cochrane Database of Systematic Reviews [Internet]. 2012; (5). Available from: http://cochranelibrarywiley.com/doi/10.1002/14651858.ED000042/abstract. 
Table 11 Excluded articles (Continued)

Justification

References of excluded articles

Included results of others reviews Caplan GA. A meta-analysis of "hospital in the home". The Medical journal of Australia. 2013;198(4):195-6. Shepperd S, Wee B, Straus SE. Hospital at home: home-based end of life care. Cochrane Database of Systematic Reviews. 2011 (7):CD009231.

Published the results in another journal Shepperd S, Doll H, Angus RM, Clarke MJ, lliffe S, Kalra L, et al. Avoiding hospital admission through provision of hospital care at home: a systematic review and meta-analysis of individual patient data. CMAJ: Canadian Medical Association Journal. 2009;180(2):175-82.

Systematic review of systematic reviews included in our study

Conley J, O'Brien CW, Leff BA, Bolen S, Zulman D. Alternative strategies to inpatient hospitalization for acute medical conditions: a systematic review. JAMA Internal Medicine. 2016;176(11):1693-702. 


\section{Appendix 6}

Table 12 Characteristics of studies included in detail

\begin{tabular}{|c|c|c|c|c|c|c|c|}
\hline $\begin{array}{l}\text { Author, } \\
\text { year, } \\
\text { country }\end{array}$ & $\begin{array}{l}\text { Type of reviews } \\
\text { or designs }\end{array}$ & $\begin{array}{l}\text { No. of } \\
\text { studies }\end{array}$ & Study country & Population & Intervention & Outcomes & AMSTAR \\
\hline $\begin{array}{l}\text { Cool et al. } \\
\text { [53], 2018, } \\
\text { Belgium }\end{array}$ & $\begin{array}{l}\text { Systematic review } \\
\text { Mixed }\end{array}$ & $\begin{array}{l}5 \mathrm{RCT}^{*} \\
2 \mathrm{nRCT^{* }} \\
7 \text { single-arm } \\
\text { prospective } \\
\text { trials } \\
2 \text { qualitative } \\
\text { studies } \\
1 \\
\text { retrospective } \\
\text { cohort study }\end{array}$ & $\begin{array}{l}\text { European countries, } \\
\text { mostly France and } \\
\text { United Kingdom } \\
\text { (UK) } \\
\text { Other studies from: } \\
\text { Belgium, Israel, } \\
\text { Germany, Ireland, } \\
\text { Spain, Switzerland, } \\
\text { Sweden, Australia, } \\
\text { Canada, and United } \\
\text { States of America } \\
\text { (USA) }\end{array}$ & Adult patients & $\begin{array}{l}\text { Parenteral cancer } \\
\text { drug administration } \\
\text { in hospital at home } \\
\text { care }\end{array}$ & $\begin{array}{l}\text { Quality of life, } \\
\text { patient's satisfaction, } \\
\text { safety, and costs }\end{array}$ & $\begin{array}{l}\text { Moderate } \\
\text { quality } \\
\text { review }\end{array}$ \\
\hline $\begin{array}{l}\text { Corral } \\
\text { Gudino } \\
\text { et al. [54], } \\
2017 \text {, Spain }\end{array}$ & $\begin{array}{l}\text { Systematic review } \\
\text { Qualitative }\end{array}$ & $\begin{array}{l}21 \text { RCTs, } \\
\text { among } \\
\text { which } 4 \text { RCTs } \\
\text { about HBH }\end{array}$ & Spain & Not specified & $\begin{array}{l}\text { Interventions } \\
\text { supporting } \\
\text { continuity of care, } \\
\text { including } \mathrm{HBH}\end{array}$ & $\begin{array}{l}\text { Number of } \\
\text { readmissions, } \\
\text { mortality, or } \\
\text { improvement in } \\
\text { functional capacity }\end{array}$ & $\begin{array}{l}\text { Moderate } \\
\text { quality } \\
\text { review }\end{array}$ \\
\hline $\begin{array}{l}\text { Goncalves- } \\
\text { Bradley } \\
\text { et al. [22], } \\
2017 \text {, UK }\end{array}$ & $\begin{array}{l}\text { Systematic review } \\
\text { and meta-analysis } \\
\text { Quantitative }\end{array}$ & 32 RCTs & $\begin{array}{l}\text { A majority of } \\
\text { studies are from the } \\
\text { UK, Australia, and } \\
\text { Norway. Other } \\
\text { studies from: } \\
\text { Canada, Chile, Italy, } \\
\text { New Zealand, Spain, } \\
\text { Sweden, Thailand, } \\
\text { The Netherlands, } \\
\text { and Turkey }\end{array}$ & $\begin{array}{l}\text { Patients aged } 18 \\
\text { years and over, } \\
\text { acute episode of } \\
\text { care }\end{array}$ & $\begin{array}{l}\text { Early discharge } \\
\text { hospital at home }\end{array}$ & $\begin{array}{l}\text { Effectiveness and } \\
\text { cost of the } \\
\text { intervention }\end{array}$ & $\begin{array}{l}\text { High } \\
\text { quality } \\
\text { review }\end{array}$ \\
\hline $\begin{array}{l}\text { Huntley } \\
\text { et al. [55], } \\
\text { 2017, UK }\end{array}$ & $\begin{array}{l}\text { Systematic review } \\
\text { Qualitative }\end{array}$ & $\begin{array}{l}10 \text { RCTs } \\
9 \text { nRCTs } \\
\text { Among them } \\
11 \text { studies ( } 6 \\
\text { RCTs and } 5 \\
\text { nRCTs) about } \\
\mathrm{HBH}\end{array}$ & $\begin{array}{l}\text { European countries, } \\
\text { principally UK }\end{array}$ & $\begin{array}{l}\text { Patients aged over } \\
65 \text { years at risk of } \\
\text { an unplanned } \\
\text { admission }\end{array}$ & $\begin{array}{l}\text { Any community- } \\
\text { based intervention } \\
\text { offered as an alter- } \\
\text { native to admission } \\
\text { to an acute hospital }\end{array}$ & $\begin{array}{l}\text { Reduction in } \\
\text { secondary care use, } \\
\text { patient-related out- } \\
\text { comes, safety, and } \\
\text { costs }\end{array}$ & $\begin{array}{l}\text { Moderate } \\
\text { quality } \\
\text { review }\end{array}$ \\
\hline $\begin{array}{l}\text { Shepperd } \\
\text { et al. [24], } \\
\text { 2016a, UK }\end{array}$ & $\begin{array}{l}\text { Systematic review } \\
\text { and meta-analysis } \\
\text { Quantitative }\end{array}$ & $\begin{array}{l}3 \text { RCTs } \\
1 \mathrm{nRCT}\end{array}$ & $\begin{array}{l}\text { Norway, UK, and } \\
\text { USA }\end{array}$ & $\begin{array}{l}\text { People aged } 18 \\
\text { years and older, } \\
\text { who would } \\
\text { otherwise require } \\
\text { hospital or hospice } \\
\text { inpatient end-of- } \\
\text { life care }\end{array}$ & $\begin{array}{l}\text { Home-based end-of- } \\
\text { life care }\end{array}$ & $\begin{array}{l}\text { Place of death, } \\
\text { unplanned/ } \\
\text { precipitous } \\
\text { admission to or } \\
\text { discharge from } \\
\text { hospital, control of } \\
\text { symptoms, delay in } \\
\text { care from point of } \\
\text { referral to } \\
\text { intervention, } \\
\text { participant health } \\
\text { outcomes, family- or } \\
\text { caregiver-reported } \\
\text { symptoms, family or } \\
\text { caregiver unable to } \\
\text { continue caring, par- } \\
\text { ticipant's preferred } \\
\text { place of death, } \\
\text { health service use, } \\
\text { including system } \\
\text { and caregiver costs }\end{array}$ & $\begin{array}{l}\text { High } \\
\text { quality } \\
\text { review }\end{array}$ \\
\hline $\begin{array}{l}\text { Shepperd } \\
\text { et al. [25], } \\
\text { 2016b, UK }\end{array}$ & $\begin{array}{l}\text { Systematic review } \\
\text { and meta-analysis } \\
\text { Quantitative }\end{array}$ & 16 RCTs & $\begin{array}{l}\text { Australia, Italy, New } \\
\text { Zealand, Romania, } \\
\text { Spain, UK, and USA }\end{array}$ & $\begin{array}{l}\text { Patients aged } 18 \\
\text { years and over } \\
\text { (older patients = } \\
65 \text { years and older). } \\
\text { Patients to be } \\
\text { clinically stable and } \\
\text { not requiring }\end{array}$ & Hospital at home & $\begin{array}{l}\text { Mortality, transfer (or } \\
\text { readmission) to } \\
\text { hospital, functional } \\
\text { status, quality of life } \\
\text { or self-reported } \\
\text { health status, cogni- } \\
\text { tive function, }\end{array}$ & $\begin{array}{l}\text { High } \\
\text { quality } \\
\text { review }\end{array}$ \\
\hline
\end{tabular}


Table 12 Characteristics of studies included in detail (Continued)

Outcomes AMSTAR

$$
\begin{aligned}
& \text { year, } \\
& \text { country }
\end{aligned}
$$

\begin{tabular}{|c|c|c|c|c|c|}
\hline $\begin{array}{l}\text { Author, } \\
\text { year, } \\
\text { country }\end{array}$ & $\begin{array}{l}\text { Type of reviews } \\
\text { or designs }\end{array}$ & $\begin{array}{l}\text { No. of } \\
\text { studies }\end{array}$ & Study country & Population & Intervention \\
\hline & & & & $\begin{array}{l}\text { specialist } \\
\text { diagnostic } \\
\text { investigation or } \\
\text { emergency } \\
\text { interventions }\end{array}$ & \\
\hline $\begin{array}{l}\text { Echevarria } \\
\text { et al. [23], } \\
\text { 2016, UK }\end{array}$ & $\begin{array}{l}\text { Systematic review } \\
\text { and meta-analysis } \\
\text { Quantitative }\end{array}$ & 7 RCTs & $\begin{array}{l}\text { UK, Netherlands, } \\
\text { Australia, Italy }\end{array}$ & $\begin{array}{l}\text { Patients with acute } \\
\text { exacerbation of } \\
\text { chronic obstructive } \\
\text { pulmonary disease }\end{array}$ & $\begin{array}{l}\text { Early supported } \\
\text { discharge (ESD) and } \\
\text { hospital at home } \\
(\mathrm{HAH})\end{array}$ \\
\hline
\end{tabular}

specialist

gnostic

emergency

interventions depression, clinical
outcomes, place of
residence at follow-
up (living in a resi-
dential setting), pa-
tient satisfaction,
caregiver outcomes,
health professionals'
views, length of stay
in hospital and hos-
pital at home, cost,
use of other health
services and informal
care

Structure of ESD/

HAH schemes,

number of patients

experiencing one or more readmissions, mortality and cost, comparing cost across different countries and healthcare structures

Qaddoura Systematic review $3 \mathrm{RCTS}$

et al. [49], and meta-analysis 3 nRCTs

2015, Quantitative

Canada

among

which 5

studies (3

RCTs and 2

$\mathrm{nRCTs}$ ) are

about $\mathrm{HBH}$

$\begin{array}{ll}\text { Caplan } & \text { Systematic review } \\ \text { et al. [20], } & \text { and meta-analysis } \\ \text { 2012, } & \text { Quantitative }\end{array}$

Australia

61 RCTs

among

which 26

RCTs about

Spain, Italy, Sweden Patients who required

hospitalization for

Substitutive care

models

decompensated

heart failure

$\mathrm{HBH}$

Jeppesen Systematic review

et al. [12], and meta-analysis

2012 ,

Quantitative

Norway

Hansson Systematic review

et al. [50], Quantitative

2011,

Denmark
Australia, Denmark, Patients with a Italy, Spain, UK

USA, Canada, and Italy

Patients with a with an acute exacerbation

Children and

\section{Patients aged $>16$ years} adolescents aged $0-18$ years with a cancer diagnosis
Mortality, hospital readmissions, other clinical, patientcentered, and cost outcomes

\section{RCTs}

1 RCT

1 contro

group

3 studies had

no true

control

group
Shepperd Systematic review et al. [51], and meta-analysis 2009, UK Quantitative

26 RCTs $\quad \begin{aligned} & \text { Countries are not } \\ & \text { explicitly } \\ & \text { mentioned }\end{aligned}$

Patients aged 18 years and over (older patients $=$ 65 years and older). People requiring long-term care needs were not included unless they mentioned
Countries are not

explicitly

mentioned

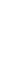

Mortality,

readmission rates, patient and carer satisfaction, and temporal- teamand disease-specific frameworks

Hospital at home care

Medical treatments relevant for childhood cancer provided by hospital- or community-based healthcare professionals who take an active part in the care in the patient's own home as an alternative to a hospital admission

\section{Early discharge} hospital at home costs

Readmission rate, mortality, costs and days of care provision

Children's physical health, adverse child satisfaction, QOL of children and their parents, and costs of using hospital data, questionnaires, or satisfaction surveys

Mortality, readmissions, quality general and disease- review specific health status, functional status, psychological wellbeing, clinical complications, patient

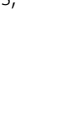

Moderate

Moderate quality review

High quality review

Moderate quality review

High quality review

Low review

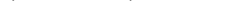


Table 12 Characteristics of studies included in detail (Continued)

\begin{tabular}{|c|c|c|c|c|c|c|c|}
\hline $\begin{array}{l}\text { Author, } \\
\text { year, } \\
\text { country }\end{array}$ & $\begin{array}{l}\text { Type of reviews } \\
\text { or designs }\end{array}$ & $\begin{array}{l}\text { No. of } \\
\text { studies }\end{array}$ & Study country & Population & Intervention & Outcomes & AMSTAR \\
\hline & & & & $\begin{array}{l}\text { required admission } \\
\text { to hospital for an } \\
\text { acute episode of } \\
\text { care }\end{array}$ & & $\begin{array}{l}\text { satisfaction, carer } \\
\text { satisfaction, carer } \\
\text { burden, staff views, } \\
\text { discharge destin- } \\
\text { ation from hospital } \\
\text { at home, length of } \\
\text { stay in hospital and } \\
\text { hospital at home, } \\
\text { cost }\end{array}$ & \\
\hline $\begin{array}{l}\text { Shepperd } \\
\text { et al. [52], } \\
\text { 2008, UK }\end{array}$ & $\begin{array}{l}\text { Systematic Review } \\
\text { and Meta-Analysis } \\
\text { Quantitative }\end{array}$ & 10 RTCS & $\begin{array}{l}\text { Australia, Italy, New } \\
\text { Zealand and the UK }\end{array}$ & $\begin{array}{l}\text { Patients aged } 18 \\
\text { years and older } \\
\text { entered the } \\
\text { program directly } \\
\text { from the } \\
\text { community or } \\
\text { from the } \\
\text { emergency } \\
\text { department }\end{array}$ & $\begin{array}{l}\text { Hospital care at } \\
\text { home }\end{array}$ & $\begin{array}{l}\text { Mortality, } \\
\text { readmissions or } \\
\text { transfers to hospital, } \\
\text { general and disease- } \\
\text { specific health status, } \\
\text { functional status, } \\
\text { psychological well- } \\
\text { being, clinical com- } \\
\text { plications, patient } \\
\text { and caregiver satis- } \\
\text { faction, caregiver } \\
\text { burden, staff per- } \\
\text { spectives, place of } \\
\text { residence at fol- } \\
\text { lowup, length of } \\
\text { stay and cost }\end{array}$ & $\begin{array}{l}\text { Moderate } \\
\text { quality } \\
\text { review }\end{array}$ \\
\hline $\begin{array}{l}\text { Felix et al. } \\
\text { [26], 2004, } \\
\text { UK }\end{array}$ & $\begin{array}{l}\text { Systematic review } \\
\text { and meta- } \\
\text { analysisQuantitative }\end{array}$ & 7 RTCs & $\begin{array}{l}\text { Spain, Australia (not } \\
\text { explicitly } \\
\text { mentioned other } \\
\text { countries included) }\end{array}$ & $\begin{array}{l}\text { Adult patients } \\
\text { attending an } \\
\text { emergency } \\
\text { department with } \\
\text { an acute } \\
\text { exacerbation } \\
\text { within } 72 \mathrm{~h} \text { of } \\
\text { presenting to the } \\
\text { department and } \\
\text { after an }\end{array}$ & $\begin{array}{l}\text { Hospital at home } \\
\text { schemes }\end{array}$ & $\begin{array}{l}\text { Mortality and } \\
\text { readmission }\end{array}$ & $\begin{array}{l}\text { Moderate } \\
\text { quality } \\
\text { review }\end{array}$ \\
\hline $\begin{array}{l}\text { Shepperd } \\
\text { et al. [44], } \\
\text { 1998, UK }\end{array}$ & $\begin{array}{l}\text { Systematic review } \\
\text { Quantitative }\end{array}$ & $5 \mathrm{RCTS}$ & UK, USA & $\begin{array}{l}\text { Patients aged } 18 \\
\text { years and over } \\
\text { needing treatment } \\
\text { during an acute } \\
\text { episode of care }\end{array}$ & $\begin{array}{l}\text { Hospital at home } \\
\text { care }\end{array}$ & $\begin{array}{l}\text { Mortality, clinical } \\
\text { complications, re- } \\
\text { admissions, costs, } \\
\text { hospital days saved } \\
\text { from the provision } \\
\text { of hospital at home, } \\
\text { discharge destin- } \\
\text { ation from hospital } \\
\text { at home, functional } \\
\text { status, psychological } \\
\text { well-being, patient } \\
\text { satisfaction, and } \\
\text { carer satisfaction }\end{array}$ & $\begin{array}{l}\text { Low } \\
\text { quality } \\
\text { review }\end{array}$ \\
\hline
\end{tabular}




\section{Appendix 7}

Table 13 Strength of evidence of reported indicators of HBH model using GRADE [46].

\begin{tabular}{|c|c|c|c|c|}
\hline Effects & [24] & [25] & [22] & [12] \\
\hline Readmission & Moderate & - & Low & Moderate \\
\hline Mortality & Moderate & - & Moderate & Moderate \\
\hline Living in an institutional setting & Low & - & Low & - \\
\hline Hospital and hospital at home length of stay & Low & - & Low & - \\
\hline Place of death (home) & - & High & - & - \\
\hline Admission to hospital & - & Moderate & - & - \\
\hline Patient satisfaction & Low & Low & Low & Low \\
\hline Caregiver burden & - & Low & - & - \\
\hline Carer satisfaction & - & - & - & Very low \\
\hline Health service cost & Low & Low & Very low & Very low \\
\hline Quality of life & - & - & - & Very low \\
\hline
\end{tabular}

Legend: GRADE Working Group grades of evidence: High certainty: further research is very unlikely to change our confidence in the estimate of effect. Moderate certainty: further research is likely to have an important impact on our confidence in the estimate of effect and may change the estimate. Low certainty: further research is very likely to have an important impact on our confidence in the estimate of effect and is likely to change the estimate. Very low certainty: we are very uncertain about the estimate

\section{Abbreviations}

AMSTAR 2: Assessing the Methodological quality of Systematic Reviewsupdate; CDSR: Cochrane Database of Systematic Reviews; CINA

HL: Cumulative Index to Nursing and Allied Health Literature; CIUSSSCN: Centre intégré universitaire de santé et services sociaux de la CapitaleNationale; COPD: Chronic obstructive pulmonary disease; DARE: Database of Abstracts of Reviews of Effects; EndNote: Bibliographic reference management software; ESD: Early supported discharge; $\mathrm{HAH}$ : Hospital at home; HBH: Home-based hospitalization; HBHC: Hospital-based home care; IT: Information technology; Medline: Medical Literature Analysis and Retrieval System Online; NCPF: Nursing care performance framework; nRTC: Nonrandomized controlled trial; PRISMA: Preferred Reporting Items for Systematic Review and Meta-Analysis; PROSPERO: International Prospective Register of Systematic Reviews; QoL: Quality of life; RTC: Randomized controlled trial

\section{Acknowledgements}

We wish to acknowledge the Canadian Institutes of Health Research in collaboration with the Centre intégré universitaire de santé et services sociaux de la Capitale-Nationale (CIUSSS-CN) in partnership with the Faculty of Nursing Sciences of Université Laval, for the research support.

\section{Authors' contributions}

All authors designed the systematic review. CPMC and MCL developed the research strategy. CPMC and GICM screened titles and abstracts of references identified in the databases and reviewed the selection and the full text articles. CPMC and GICM extracted the data, and CPMC synthetized the data and wrote the results. All authors participated to the drafting of the manuscript and reviewed its content. All authors approved the final version of the manuscript.

\section{Funding}

This research was funded by the Canadian Institutes of Health Research as part of a Training Modernization Start-Up Grant and a Health System Impact postdoctoral fellowship to CPMC, in collaboration with the Centre intégré universitaire de santé et services sociaux de la Capitale-Nationale (CIUSSS$\mathrm{CN}$ ) in partnership with the Faculty of Nursing Sciences of Université Laval.

\section{Availability of data and materials}

All data generated or analyzed during this study are included in this published article and its supplementary information files.

\section{Ethics approval and consent to participate}

Not applicable.

\section{Consent for publication}

Not applicable.

\section{Competing interests}

The authors have no competing interests to declare.

\section{Author details}

${ }^{1}$ Faculty of Nursing Sciences, Université Laval, Québec City, QC, Canada.

${ }^{2}$ University Health and Social Services Centre (IUHSSC) of Capitale-Nationale (CN), Québec City, QC, Canada. ${ }^{3}$ School of Social Work, Université Laval, Québec City, QC, Canada. ${ }^{4}$ Primary Care and Services Research Center, Université Laval - Primary Health Care and Social Services University Institute, IUHSSC-CN, Québec City, QC, Canada. ${ }^{5}$ Research Center of the CHU de Québec-Université Laval, 1050 Avenue de la Médecine. Pavillon Ferdinand-Vandry, Québec City, QC G1V0A6, Canada. ${ }^{6}$ Center of Excellence on Aging Quebec (CEVQ), IUHSSC-CN, Québec City, QC, Canada. 'Library, Université Laval, Québec City, QC, Canada.

Received: 2 December 2019 Accepted: 10 July 2020

Published online: 08 August 2020

\section{References}

1. Rodrigues R, Huber M. G L. Facts and figures on healthy ageing and longterm care. Vienna: European Centre for Social Welfare Policy and Research; 2012.

2. Connor SR, Gwyther E. The Worldwide Hospice Palliative Care Alliance. Journal of Pain and Symptom Management. 2018;55(2):S112-S6.

3. Davy C, Bleasel J, Liu H, Tchan M, Ponniah S, Brown A. Effectiveness of chronic care models: opportunities for improving healthcare practice and health outcomes: a systematic review. BMC Health Services Research. 2015; 15(1)

4. Dumont $\mathrm{S}$, Jacobs $\mathrm{P}$, Fassbender $\mathrm{K}$, Anderson D, Turcotte V, Harel F. Costs associated with resource utilization during the palliative phase of care: a Canadian perspective. Palliat Med. 2009;23(8):708-17.

5. Lee DC, Carr B, Smith T, Tran V, Polsky D, Branas C. The impact of hospital closures and hospital and population characteristics on increasing emergency department volume: a geographic analysis. Population Health Management. 2015;18(6):459-66.

6. Pines JM, Hilton JA, Weber EJ, Alkemade AJ, Al Shabanah H, Anderson PD, et al. International perspectives on emergency department crowding. Academic Emergency Medicine. 2011;18(12):1358-70.

7. Harris A, Sharma A. Access block and overcrowding in emergency departments: an empirical analysis. Emergency Medicine Journal. 2010; 27(7):508.

8. Lakhan P, Jones M, Wilson A, Courtney M, Hirdes J, Gray LC. A prospective cohort study of geriatric syndromes among older medical patients admitted to acute care hospitals. Journal of the American Geriatrics Society. 2011; 59(11):2001-8 
9. Hwang U, Dresden SM, Rosenberg MS, Garrido MM, Loo G, Sze J, et al. Geriatric Emergency department innovations: transitional care nurses and hospital use. Journal of the American Geriatrics Society. 2018;66(3):459-66.

10. Varney JJ, Weiland JT, Jelinek JG. Efficacy of hospital in the home services providing care for patients admitted from emergency departments: an integrative review. International Journal of Evidence-Based Healthcare. 2014; 12(2):128-41.

11. Montalto M, Lui B, Mullins A, Woodmason K. Medically-managed hospital in the home: 7 year study of mortality and unplanned interruption. Australian health review : a publication of the Australian Hospital Association. 2010; 34(3):269.

12. Jeppesen E, Brurberg K, Vist G, Wedzicha J, Wright J, Greenstone M, et al. Hospital at home for acute exacerbations of chronic obstructive pulmonary disease. Cochrane Database of Systematic Reviews. 2012;5(5).

13. Fédération Nationale des Etablissements d'Hospitalisation à Domicile. L'hospitalisation à domicile, une exception française? . Paris: Fédération nationale des établissements d'hospitalisation à domicile; 2016.

14. Leff B, Burton L, Mader SL, Naughton B, Burl J, Greenough WB, et al. Comparison of functional outcomes associated with hospital at home care and traditional acute hospital care. Journal of the American Geriatrics Society. 2009;57(2):273-8.

15. Vilà A, Villegas E, Cruanyes J, Delgado R, Sabaté RA, Ortega J, et al. Costeffectiveness of a Barcelona home care program for individuals with multimorbidity. Journal of the American Geriatrics Society. 2015;63(5):1017-24.

16. Crilly J, Chaboyer W, Wallis M. A structure and process evaluation of an Australian hospital admission avoidance programme for aged care facility residents. Journal of Advanced Nursing. 2012;68(2):322-34.

17. Lemelin J, Hogg W, Dahrouge S, Armstrong CD, Martin CM, Zhang W, et al. Patient, informal caregiver and care provider acceptance of a hospital in the home program in Ontario, Canada. BMC Health Services Research. 2007;7(1).

18. Lee G, Sakone P, Mulhall H, Kelleher K, Burnett K. Using hospital at home to reduce admissions.(Report). Nursing Times. 2015;111(36 37):12-5.

19. De Stampa M, Marquestaut O, Mac E, Loffredo M-L, Andrieu M. Coordination in hospital-based home care. Soins Gerontologie. 2014;107:33.

20. Caplan GA, Sulaiman NS, Mangin DA, Ricauda NA, Wilson AD, Barclay L. A meta-analysis of "hospital in the home". Medical Journal of Australia. 2012; 197(9):512-519.

21. Veyron J-H. Hospitalisation à domicile (ANAP). État des lieux et outils d'analyse au niveau territorial. France. 2018;2018.

22. Goncalves-Bradley DC, lliffe S, Doll HA, Broad J, Gladman J, Langhorne P, et al. Early discharge hospital at home. Cochrane Database Syst Rev. 2017;6: CD000356.

23. Echevarria C, Brewin K, Horobin H, Bryant A, Steer J, Bourke SC. Early supported discharge/hospital at home for exacerbation of chronic obstructive pulmonary disease, a review and meta-analysis. European Respiratory Journal. 2016;48(suppl 60):PA3772.

24. Shepperd S, Gonçalves-Bradley DC, Straus SE, Wee B. Hospital at home: home-based end-of-life care. Cochrane Database Syst Rev. 2016;2:CD009231.

25. Shepperd S, lliffe S, Doll HA, Clarke MJ, Kalra L, Wilson AD, et al. Admission avoidance hospital at home. Cochrane Database Syst Rev. 2016;9:CD007491.

26. Felix SFR, Wedzicha JA, Wright J, Greenstone M. Hospital at home for patients with acute exacerbations of chronic obstructive pulmonary disease: systematic review of evidence. British Medical Journal. 2004;329(7461):315.

27. Boland L, Legare F, Perez M, Menear M, Garvelink MM, Mclsaac Dl, et al. Impact of home care versus alternative locations of care on elder health outcomes: an overview of systematic reviews. BMC Geriatrics. 2017;17(1)

28. Nordly M, Vadstrup ES, Sjøgren P. Kurita GP. Home-based specialized palliative care in patients with advanced cancer: a systematic review. 2016; 14(6):713-24.

29. Macdonald-Wilson K. Hutchison, Shari, Karpov I, Wittman P, et al. A successful implementation strategy to support adoption of decision making in mental health services. Community Mental Health Journal. 2017;53(3):251-6.

30. Mckillop A, Shaw J, Sheridan N, Gray C, Carswell P, Wodchis W, et al. Understanding the attributes of implementation frameworks to guide the implementation of a model of community-based integrated health care for older adults with complex chronic conditions: a metanarrative review. International Journal of Integrated Care. 2017;17(2):10.

31. Hutton B, Salanti G, Caldwell DM, Chaimani A, Schmid CH, Cameron C, et al. The PRISMA extension statement for reporting of systematic reviews incorporating network meta-analyses of health care interventions: checklist and explanations. Ann Intern Med. 2015;162(11):777-84.
32. Higgins J, Green S. Cochrane Handbook for Systematic Reviews of Interventions. Version 5.1.0: the Cochrane Collaboration. 2011. Available from: http://handbook.cochrane.org.

33. Pollock M, Fernandes RM, Becker LA, Featherstone R, Hartling L. What guidance is available for researchers conducting overviews of reviews of healthcare interventions? A scoping review and qualitative metasummary. Syst Rev. 2016;5(1):190

34. Hunt H, Pollock A, Campbell P, Estcourt L, Brunton G. An introduction to overviews of reviews: planning a relevant research question and objective for an overview. Syst Rev. 2018;7(1):39.

35. Shea BJ, Reeves BC, Wells G, Thuku M, Hamel C, Moran J, et al. AMSTAR 2: a critical appraisal tool for systematic reviews that include randomised or non-randomised studies of healthcare interventions, or both. BMJ. 2017:358

36. Dubois C-A, D'Amour D, Pomey M-P, Girard F, Brault I. Conceptualizing performance of nursing care as a prerequisite for better measurement: a systematic and interpretive review.(Report). BMC Nursing. 2013;12(1).

37. Ben BR. Pilotage opérationnel des structures d'hospitalisation à domicile. Institut national des sciences appliquées de Lyon: Lyon; 2010.

38. Sentilhes-Monkam A. Rétrospective de l'hospitalisation à domicile. Revue française des affaires sociales. 2005;n 3(3):157-82.

39. Farfan-Portet M, Alain D, Lut M, Francois D, Mistiaen P, Gerkens S. Implementation of hospital at home: orientations for Belgium. Health Services Research (HSR) Brussels: Belgian Health Care Knowledge Centre (KCE); 2015.

40. McGinn C, Grenier S, Duplantie J, Shaw N, Sicotte C, Mathieu L, et al. Comparison of user groups' perspectives of barriers and facilitators to implementing electronic health records: a systematic review. BMC Med. 2011;9(1).

41. Gagnon M-P, Desmartis M, Labrecque M, Car J, Pagliari C, Pluye $P$, et al. Systematic review of factors influencing the adoption of information and communication technologies by healthcare professionals. Journal of Medical Systems. 2012;36(1):241-77.

42. Gagnon M-P, Nsangou É-R, Payne-Gagnon J, Grenier S, Sicotte C. Barriers and facilitators to implementing electronic prescription: a systematic review of user groups' perceptions. Journal of the American Medical Informatics Association. 2014;21(3):535-41.

43. Gagnon M-P, Ngangue P, Payne-Gagnon J, Desmartis M. m-Health adoption by healthcare professionals: a systematic review. Journal of the American Medical Informatics Association. 2016:23(1):212-20.

44. Shepperd S, lliffe $\mathrm{S}$. The effectiveness of hospital at home compared with in-patient hospital care: a systematic review. J Public Health Med. 1998;20(3): $344-50$

45. Liberati A, Altman DG, Tetzlaff J, Mulrow C, Gøtzsche PC, loannidis JPA, et al. The PRISMA statement for reporting systematic reviews and meta-analyses of studies that evaluate health care interventions: explanation and elaboration. PLoS Medicine. 2009;6(7):e1000100.

46. Guyatt GH, Oxman AD, Kunz R, Vist GE, Falck-Ytter Y, Schunemann HJ. What is "quality of evidence" and why is it important to clinicians? Bmj. 2008; 336(7651):995-998.

47. Popay J, Roberts H, Sowden A, Petticrew M, Arai L, Rodgers M, et al. Guidance on the conduct of narrative synthesis in systematic reviews: a product from the ESRC Methods Programme: Lancaster University; 2006.

48. Rodgers M, Sowden A, Petticrew M, Arai L, Roberts H, Britten N, et al. Testing methodological guidance on the conduct of narrative synthesis in systematic reviews: effectiveness of interventions to promote smoke alarm ownership and function. Evaluation. 2009:15(1):49-73.

49. Qaddoura A, Yazdan-Ashoori P, Kabali C, Thabane L, Haynes R, Connolly SJ, et al. Efficacy of hospital at home in patients with heart failure: a systematic review and meta-analysis. PLOS ONE. 2015;10(6).

50. Hansson H, Hallstrom I, Kjaergaard H, Johansen C, Schmiegelow K. Hospitalbased home care for children with cancer. Pediatr Blood \& Cancer. 2011; 57(3):369-77.

51. Shepperd S, Doll H, Broad J, Gladman J, lliffe S, Langhorne P, et al. Hospital at home early discharge. The Cochrane database of systematic reviews. 2009(1):CD000356-CD

52. Shepperd S, Doll H, Angus RM, Clarke MJ, Iliffe S, Kalra L, et al. Hospital at home admission avoidance. The Cochrane database of systematic reviews. 2008(4):CD007491-CD

53. Cool L, Vandijck D, Debruyne $P$, Desmedt $M$, Lefebvre $T$, Lycke $M$, et al. Organization, quality and cost of oncological home-hospitalization: a systematic review. Critical Reviews in Oncology / Hematology. 2018;126: 145-53. 
54. Corral Gudino L, Borao Cengotita-Bengoa M, Jorge Sánchez RJ, García Aparicio J. The patient and the crossing between primary and hospital care. Systematic review of trials for the implementation of tools for integration in Spain. Anales del sistema sanitario de Navarra. 2017:0(0):59498.

55. Huntley AL, Chalder M, Shaw ARG, Hollingworth W, Metcalfe C, Benger JR, et al. A systematic review to identify and assess the effectiveness of alternatives for people over the age of 65 who are at risk of potentially avoidable hospital admission. BMJ Open. 2017;7(7).

56. Higgins J, Altman D, Jonathan A. Assessing risk of bias in included studies: the Cochrane Collaboration; 2011. Available from: http://handbook. cochrane.org.

57. Carvalho A, Silva V, Grande A. Avaliação do risco de viés de ensaios clínicos randomizados pela ferramenta da colaboração Cochrane. Diagn Tratamento. 2013;18(1):38-44.

58. Conley J, O'Brien CW, Leff BA, Bolen S, Zulman D. Alternative strategies to inpatient hospitalization for acute medical conditions: a systematic review. JAMA Intern Med. 2016;176(11):1693-702.

\section{Publisher's Note}

Springer Nature remains neutral with regard to jurisdictional claims in published maps and institutional affiliations.

Ready to submit your research? Choose BMC and benefit from:

- fast, convenient online submission

- thorough peer review by experienced researchers in your field

- rapid publication on acceptance

- support for research data, including large and complex data types

- gold Open Access which fosters wider collaboration and increased citations

- maximum visibility for your research: over $100 \mathrm{M}$ website views per year

At BMC, research is always in progress.

Learn more biomedcentral.com/submissions 